\title{
Bioconcentration of Organotin Cations during Molting Inhibits Heterocypris incongruens Growth
}

\author{
Tom M. Nolte,* Ward De Cooman, Jos P. M. Vink, Raf Elst, Els Ryken, Ad M. J. Ragas,
} and A. Jan. Hendriks

Cite This: Environ. Sci. Technol. 2020, 54, 14288-14301

Read Online

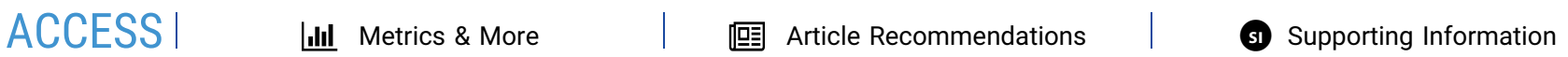

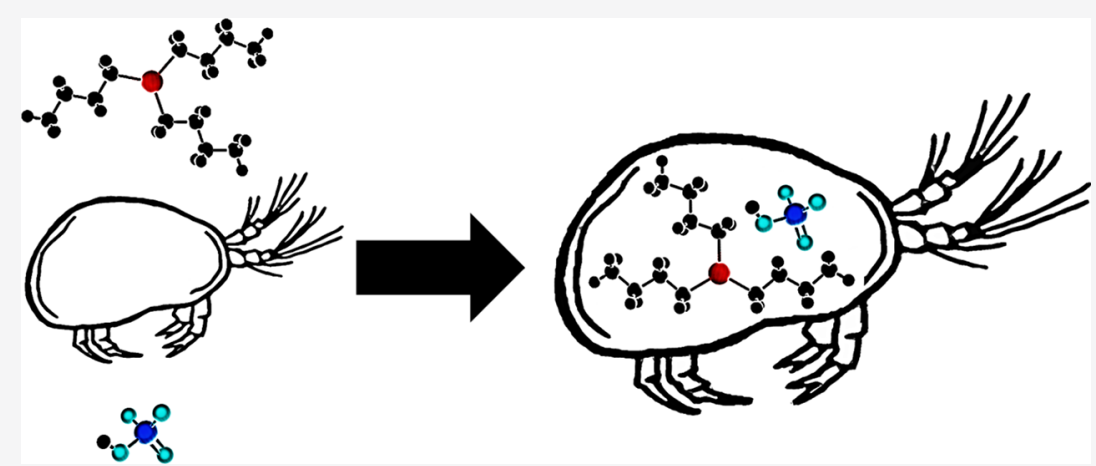

ABSTRACT: The densely populated North Sea region encompasses catchments of rivers such as Scheldt and Meuse. Herein, agricultural, industrial, and household chemicals are emitted, transported by water, and deposited in sediments, posing ecological risks. Though sediment monitoring is often costly and time-intensive, modeling its toxicity to biota has received little attention. Due to high complexity of interacting variables that induce overall toxicity, monitoring data only sporadically validates current models. Via a range of concepts, we related bio-physicochemical constituents of sediment in Flanders to results from toxicity bioassays performed on the ostracod Heterocypris incongruens. Depending on the water body, we explain up to $90 \%$ of the variance in $H$. incongruens growth. Though variable across Flanders' main water bodies, organotin cations and ammonia dominate the observed toxicity according to toxic unit (TU) assessments. Approximately $10 \%$ relates to testing conditions/setups, species variabilities, incoherently documented pollutant concentrations, and/or bio-physicochemical sediment properties. We elucidated the influence of organotin cations and ammonia relative to other metal(oxides) and biocides. Surprisingly, the tributylin cation appeared $\sim 1000$ times more toxic to $H$. incongruens as compared to "single-substance" bioassays for similar species. We inferred indirect mixture effects between organotin, ammonia, and phosphate. Via chemical speciation calculations, we observed strong physicochemical and biological interactions between phosphate and organotin cations. These interactions enhance bioconcentration and explain the elevated toxicity of organotin cations. Our study aids water managers and policy makers to interpret monitoring data on a mechanistic basis. As sampled sediments differ, future modeling requires more emphasis on characterizing and parametrizing the interactions between bioassay constituents. We envision that this will aid in bridging the gap between testing in the laboratory and field observations.

\section{INTRODUCTION}

Despite decreasing emissions, ${ }^{1,2}$ persistent chemicals can remain in the aquatic ecosystem for decades (legacy pollutants $)^{3}$ because they bind physicochemically to sediment. ${ }^{4}$ Changing bio-physicochemical conditions can render pollutants bioavailable again to let them re-initiate adverse effects on aquatic organisms. ${ }^{5,6}$ Thus, sediment "quality" is crucial to the health of an aquatic ecosystem. 7,8

As a combination of species from different trophic levels and effect endpoints characterizes an ecosystem's resilience, ${ }^{9-11}$ bioassays/test batteries for daphnia, algae, midge larvae, or bacteria $^{12,13}$ are common to establish a weight of evidence approaches for sediment quality. Toxic effects vary not only between organisms and life stages $^{14,15}$ but also due to differences in exposure regimes and sediment properties: one can use the solution as extracted from sediment ${ }^{16}$ to evaluate "dissolved" contaminants or exposure to whole sediment to elucidate more integrated effects.

Received: May 6, 2020

Revised: September 30, 2020

Accepted: October 2, 2020

Published: November 2, 2020

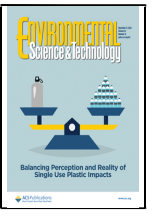


A variety of chemometric methods attempt to explain the observed effects ${ }^{17-19}$ and have shown that toxicity often does not relate to dry weight pollutant concentration. ${ }^{20}$ Establishing dose-effect relationships with data from field studies is more difficult than that from spiking with single chemicals. Testing may not agree with field observations at all. ${ }^{21,22}$ Many interactions between sediment constituents can attenuate or amplify toxic effects, more so than for surface water, which hampers selection of a proper dose metric. ${ }^{23}$ Relations between bioassays and physicochemical constituents of sediment in the field are scarce, and quantitative predictions based thereon are elusive.

Among recent progress, ${ }^{24-27}$ insight into the extent of additional available binding capacity via sediment properties allowed correct identification of toxicity. ${ }^{28}$ Both the apparent bioavailability and toxicity relate to chemical speciation. Speciation is the quantitative distribution of all chemical forms of a compound over all possible phases, as a function of bio-physicochemical properties of the endemic solution: $\mathrm{pH}$, hardness, redox conditions, and natural catalysts (clays, microorganisms). These factors vary geographically. ${ }^{29,30}$

The North Sea region has a documented history in pollution linked to industrial (heavy metals, acidification ${ }^{31}$ ) and agricultural (e.g., eutrophication) activities. ${ }^{32-34}$ An extensive measurement campaign by the Flemish Environmental Agency $(\mathrm{VMM})^{32}$ has existed in Flanders for approximately 20 years, gathering information on pollutants in 1000+ sampling locations (e.g., metals, polycyclic hydrocarbons), in conjunction with characteristics known to affect speciation/ bioavailability. Built hereon, models linked $>60 \%$ of the observed variance in Hyalella azteca mortality bioassays to heavy metals and $\mathrm{NH}_{3} / \mathrm{NH}_{4}{ }^{+}$.

Given the amount of pollutants and sediments to be evaluated and monitored, bioassay(s) should entail limited redundancy so as to capture the bulk of the potential effects with minimum effort and cost. ${ }^{36}$ Given their sensitivities, Chlorella vulgaris and Ceriodaphnia dubia may be suitable to evaluate metals, ${ }^{37}$ whereas Daphnia magna and Raphidocelis subcapitata may be more applicable to metallic/metal oxide nanomaterials. ${ }^{38}$ For Flanders, the question would be: which causal relationships between constituents of polluted sediment and ecotoxicological effects allow us to prioritize or complement bioassays?

Ostracod microcrustaceans are keystone meiofauna species in production and community metabolism of micro- or mesocosm freshwater beds. ${ }^{39}$ Present in diverse freshwater benthic habitats (ponds, lakes) in all continents, ostracods prove to be bioindicators when other species fall short. ${ }^{40}$ Many campaigns entail tests with Heterocypris incongruens (seed shrimp). ${ }^{41-44} \mathrm{H}$. incongruens is substantially more sensitive than midge larvae ${ }^{45}$ and comparably sensitive (to heavy metals, $\mathrm{NH}_{4}^{+}$) with $H$. azteca, ${ }^{41}$ but $H$. incongruens growth is particularly sensitive. ${ }^{39}$ As Flanders is an urbanized coastal (maritime) and agricultural region, concentrations of organotins (antifouling endocrine disruptors) ${ }^{46-48}$ and phosphate ${ }^{49,50}$ could be elevated and particularly relevant for growth.

Given the potentially higher sensitivity of $H$. incongruens growth to sediments in Flanders and its dissimilarity with other bioassays, we set out to build a quantitative model for predicting ostracod growth inhibition. Using extensive monitoring data in Flanders, we accounted for bioavailability and chemical speciation to develop a predictive model based on toxic unit $(\mathrm{TU})^{51}$ calculations linking concentration to effect. We predict ostracod growth inhibition with appreciable certainty, $\sim 90 \%$. Our method underpins that ostracods complement other bioindicators and supplements the existing suite of models.

\section{MATERIALS AND METHODS}

In the current study, we quantitatively predict the growth inhibition of $H$. incongruens as would be observed when exposed to sediment. As an empirical exercise, we utilized the results from bioassays as obtained from our Flemish VMM monitoring campaign. Bioassays are detailed in Section 2.6 and elsewhere. $^{45}$

Input variables for our predictions were dry weight concentrations of various chemicals. Following a recent study, ${ }^{35}$ we considered heavy metals, nitrogen, and phosphorus. Given exposure history, we also hypothesized local toxic effects by organotins. As variables, we also used common sediment characteristics: $\mathrm{pH}$, organic carbon, clay, and the nitrogen status. Physicochemical sampling of sediments and analytical methods are detailed in the Supporting Information (Section S0) and elsewhere. ${ }^{13,32} \mathrm{We}$ describe the parametrization below (Sections 2.1-2.5).

2.1. Estimation of Ammonia and Phosphate in Sediment. Data on aqueous concentrations of $\mathrm{NH}_{4}^{+}$and $\mathrm{H}_{2} \mathrm{PO}_{4}{ }^{-} / \mathrm{HPO}_{4}{ }^{2-}$ are either scattered, unrepresentative, or their uncertainties are fairly high. ${ }^{13,32,35}$ This is partially due to their high mobilities. Therefore, we estimate $\mathrm{H}_{2} \mathrm{PO}_{4}^{-}$and $\mathrm{HPO}_{4}^{2-}$ from the total phosphorus, $P_{\mathrm{T}}$

$$
\left[\mathrm{H}_{2} \mathrm{PO}_{4}^{-}\right]_{\text {sed }}+\left[\mathrm{HPO}_{4}{ }^{2-}\right]_{\text {sed }}=f_{\mathrm{P}} \cdot\left[P_{\mathrm{T}}\right]_{\text {sed }}
$$

with $f$ being a ratio applied to total $\mathrm{P}$ to distinguish for available fractions: a typical natural water body $\left(P_{\mathrm{T}} \sim 23\right.$ or $\sim 30 \mathrm{mg} / \mathrm{m}^{3}$ ) constitutes $3 \mathrm{mg} / \mathrm{m}^{3}$ soluble $\mathrm{H}_{2} \mathrm{PO}_{4}{ }^{-}+\mathrm{HPO}_{4}{ }^{2-}$ and usual $\left(\mathrm{H}_{2} \mathrm{PO}_{4}^{-}+\mathrm{HPO}_{4}{ }^{2-}\right) / P_{\mathrm{T}}$ ratios of $1: 10$. Hence, $f_{\mathrm{P}}=0.1$. $^{52}$

In turn, we estimate $\mathrm{NH}_{4}^{+}$and $\mathrm{NH}_{3}$ concentrations from the Kjeldahl nitrogen $(\mathrm{KjN})$ and eq 2

$$
\begin{aligned}
& {\left[\mathrm{NH}_{4}^{+}\right]_{\mathrm{sed}}+\left[\mathrm{NH}_{3}\right]_{\mathrm{sed}}} \\
& \quad=f_{\mathrm{N}} \cdot[\mathrm{KjN}]_{\mathrm{sed}}+s \cdot f_{\mathrm{N}} \cdot[\mathrm{KjN}]_{\mathrm{sed}} \cdot \sin \left(\frac{2 \pi}{365} d+65\right)
\end{aligned}
$$

wherein $f_{\mathrm{N}}$ is taken as the fraction of the $\mathrm{KjN}$ that is $\left[\mathrm{NH}_{4}^{+}\right]+$ $\left[\mathrm{NH}_{3}\right]$, taken to be $0.5( \pm 0.1){ }^{53,54}$ Exclusive for the data in West Flanders $(s=1$, else $s=0)$, we applied a sinoid term with maximal amplitude (peak) in mid-march $(d=65)^{55,56}$ to account for local seasonal (agricultural) fluctuations ${ }^{57,58}$ (S1). If the data adhering to negative growth inhibition (Section 2.6) did not entail $\mathrm{KjN}$ determination, we applied the log-average of samples analyzed throughout Flanders. To prevent bias, we excluded those sediments that we already selected from curation (Section 2.6).

2.2. Bioavailability. Toxicity is most often associated with the fraction of the chemical that is freely bioavailable. Though test vessels contained sediment, ${ }^{13,59}$ we had no information on burrowing behavior. We assumed that all ostracods are exposed to chemicals in the water phase. From our campaign, we obtained only the total sediment concentrations. Since those sediments are applied to the (aqueous) bioassay, we estimate in situ water concentrations from the total in sediment. 
We converted sediment (sed) concentrations to water (aq) concentrations via phase partitioning ${ }^{60,61}$

$$
\left[C_{i}\right]_{\mathrm{aq}}=0.2 \cdot \frac{\left[C_{i}\right]_{\mathrm{sed}}}{1+K_{\mathrm{SW}, \text { local }}}
$$

wherein 0.2 represents the sediment to test volume ratio $\left(1: 5^{45}\right)$. Considering that the test medium is prescribed as moderately hard, ${ }^{13}$ we took the value for the solids-to-water partitioning coefficient $K_{\mathrm{SW} \text {, local }}$ for $\mathrm{NH}_{4}^{+} / \mathrm{NH}_{3}$ and $\mathrm{H}_{2} \mathrm{PO}_{4}^{-}$/ $\mathrm{HPO}_{4}{ }^{2-}$ to be $6.0( \pm 3.0)^{62-65}$ and $100 \mathrm{~L} / \mathrm{kg}^{66,67}$ respectively, for field concentrations ${ }^{64-66}$ representable for Flanders ${ }^{13,32,35}$ and $\mathrm{pH}=7.4$.

The binding of metals is stronger in sediments with increasing clay and organic carbon (OC), ${ }^{68,69}$ creating a natural "bias". Thus, we calculated $K_{S W, l o c a l}$ based on \%clay and $\% \mathrm{OC}$ content, analogous to Bruijn and Denneman ${ }^{70}$

$$
\begin{aligned}
\log \left(K_{\text {SW,local,metals }}\right)= & \log \left(K_{\text {SW }}\right)-\left[a \cdot \log \left(\frac{5}{\% \mathrm{OC}}\right)\right. \\
& \left.+b \cdot \log \left(\frac{11}{\% \text { clay }}\right)\right]
\end{aligned}
$$

wherein we obtained the solid-water partition coefficient $\left(K_{\mathrm{SW}}\right)$ from the literature, ${ }^{60,71,72}$ representing a mix of speciation states. $K_{\mathrm{SW}}$ values were assumed to represent $11 \%$ clay and $5 \%$ OS. $^{13,68} a$ and $b$ are the concentrations $(\mathrm{mg} / \mathrm{kg}$ dissolved substances) of metals per \%clay and \%OS, respectively, based on (log-log) multiple linear regression (MLR) for the entire VMM (Flanders) data set $(N=1762)$ :

$$
\log \left(\left[C_{i}\right]_{\text {sed,metals }}\right)=a \cdot \log (\% \text { OS })+b \cdot \log (\% \text { clay })
$$

Considering their hydrophobicity, we estimated $K_{\mathrm{SW} \text {,local }}$ for organotins from their organic carbon partition coefficients $\left(K_{\mathrm{OC}}\right)$ and the \%OC content (varying $\left.10 \gtrsim \% \mathrm{OC} \gtrsim 0.1^{13,32}\right)$ :

$$
K_{\mathrm{SW}, \text { local,organotins }}=K_{\mathrm{OC}} \cdot \frac{\% \mathrm{OC}}{100}
$$

Sediment and biota affect the in situ ionic composition of the medium, ${ }^{73,74}$ though the influence of salinity ${ }^{75,76}$ on organotin sorption is conflicting (salting out vs. cation exchange). We also lacked information on the relevant OC type. ${ }^{75}$ Hence, we did not consider influences of salinity and $\mathrm{pH}$ on $\mathrm{K}_{\mathrm{OC}}$. Instead, we applied log-normal averages for $K_{\mathrm{OC}}$ values reported for fresh and marine sediments (Table 1).

2.3. Speciation. Toxicity is often the result of a specific speciation state of a chemical; heavy metals, organotins, phosphate, and ammonia are subject to adopt different speciation. Thus, we describe explicitly the influence of the (bio)chemical properties of the endemic solution.

Phosphate may act both as a toxicant ${ }^{49}$ and a nutrient, ${ }^{50}$ whereas organotins and ammonium are toxicants. Prominently, the fraction of nonionized ammonium often relates to observed toxicity. ${ }^{77}$ The species (de)protonate according to

\begin{tabular}{|c|c|c|c|}
\hline chemical & $\log K_{\mathrm{OC}}{ }^{75}$ & $\log K_{\mathrm{SW}}$ & ref \\
\hline tetrabutyltin & $5.5( \pm 0.1)$ & $4.2( \pm 0.1)^{a}$ & 75 \\
\hline tributyltin & $5.3( \pm 0.1)$ & $4.0( \pm 0.1)^{a}$ & 75 \\
\hline dibutyltin & $5.2( \pm 0.2)$ & $3.9( \pm 0.2)^{a}$ & 75 \\
\hline monobutyltin & $5.0( \pm 0.2)$ & $3.7( \pm 0.2)^{a}$ & 75 \\
\hline triphenyltin & $4.9( \pm 0.1)$ & $3.6( \pm 0.2)^{a}$ & 75 \\
\hline diphenyltin & $4.7( \pm 0.2)$ & $3.4( \pm 0.2)^{a}$ & 75 \\
\hline monophenyltin & $4.4( \pm 0.3)$ & $3.1( \pm 0.2)^{a}$ & 75 \\
\hline $\mathrm{NH}_{4}^{+} / \mathrm{NH}_{3}$ & $\mathrm{n} / \mathrm{a}$ & $0.8^{b}$ & 62,65 \\
\hline $\mathrm{H}_{2} \mathrm{PO}_{4}{ }^{-} / \mathrm{HPO}_{4}{ }^{2-}$ & $\mathrm{n} / \mathrm{a}$ & $2.0( \pm 0.5)^{b}$ & 66 \\
\hline $\mathrm{Cd}$ & $\mathrm{n} / \mathrm{a}$ & $2.1^{a}$ & 60 \\
\hline $\mathrm{Cr}$ & $\mathrm{n} / \mathrm{a}$ & $2.5^{a}$ & 60 \\
\hline $\mathrm{Cu}$ & $\mathrm{n} / \mathrm{a}$ & $1.7^{a}$ & 60 \\
\hline $\mathrm{Hg}$ & $\mathrm{n} / \mathrm{a}$ & $2.2^{a}$ & 60 \\
\hline $\mathrm{Ni}$ & $\mathrm{n} / \mathrm{a}$ & $0.9^{a}$ & 60 \\
\hline $\mathrm{Pb}$ & $\mathrm{n} / \mathrm{a}$ & $2.8^{a}$ & 60 \\
\hline $\mathrm{Zn}$ & $\mathrm{n} / \mathrm{a}$ & $2.0^{a}$ & 60 \\
\hline
\end{tabular}

$$
\begin{aligned}
& {\left[\mathrm{NH}_{4}^{+}\right]_{\mathrm{aq}} \underset{k_{-1}}{\stackrel{k_{1}}{\rightleftharpoons}}\left[\mathrm{NH}_{3}\right]_{\mathrm{aq}}+\mathrm{H}^{+}} \\
& {\left[\mathrm{H}_{2} \mathrm{PO}_{4}^{-}\right]_{\mathrm{aq}} \underset{k_{-2}}{\stackrel{k_{2}}{\rightleftharpoons}}\left[\mathrm{HPO}_{4}{ }^{2-}\right]_{\mathrm{aq}}+\mathrm{H}^{+}}
\end{aligned}
$$

\section{Table 1. Sorption Equilibrium Partitioning Coefficients}

${ }^{a}$ Taken to represent sediments in Flanders with 5\% OC and $11 \%$ and clay. ${ }^{b}$ Taken for all sediments in Flanders.

$$
\left[\mathrm{Sn}(\mathrm{OH})_{3-n} \mathrm{OH}_{2} \mathrm{R}_{n}{ }^{+}\right]_{\mathrm{aq}} \underset{k_{-3}}{\stackrel{k_{3}}{\rightleftharpoons}}\left[\mathrm{Sn}(\mathrm{OH})_{4-n} \mathrm{R}_{n}\right]_{\mathrm{aq}}+\mathrm{H}^{+}
$$

We thus determine their speciation via Henderson-Hasselbalch $^{78}$

$$
\begin{aligned}
& \log \left(\frac{\left[\mathrm{X}^{n}\right]_{\mathrm{aq}}}{\left[\mathrm{XH}^{n+1}\right]_{\mathrm{aq}}}\right)=\mathrm{pH}-\mathrm{pK}_{\mathrm{a}, \mathrm{XH}^{n+1}} \\
& \log \left(\left[\mathrm{XH}^{n+1}\right]_{\mathrm{aq}}\right)=\log \left(\left[\mathrm{X}^{n}\right]_{\mathrm{aq}}\right)-\left(\mathrm{pH}-\mathrm{p} K_{\mathrm{a}, \mathrm{CX}}\right)
\end{aligned}
$$

wherein $\mathrm{p} K_{\mathrm{a}}\left(\mathrm{XH}^{n+1}=\mathrm{NH}_{4}^{+}\right)=9.25$ and $\mathrm{p} K_{\mathrm{a}}\left(\mathrm{XH}^{n+1}=\right.$ $\left.\mathrm{H}_{2} \mathrm{PO}_{4}^{-}\right)=7.2$. We took the $\mathrm{p} K_{\mathrm{a}}$ values for organotins from the literature (Table 2).

$\mathrm{Cr}$ toxicity relates to the presence of $\mathrm{CrO}_{4}{ }^{2-85,86}$ via microbial (nitrification, ${ }^{87-89}$ eutrophication ${ }^{33}$ ) and redox processes: ${ }^{90}\left[\mathrm{CrO}_{4}{ }^{2-}\right]$ correlates with $\left[\mathrm{NO}_{3}{ }^{-}\right]$and $\mathrm{pH}^{91}$ due to (bio)chemical reactions

$$
\begin{aligned}
& 2\left[\mathrm{NH}_{4}^{+}\right]+4\left[\mathrm{O}_{2}\right] \underset{k_{-4}}{\stackrel{k_{4}}{\rightleftharpoons}} 2\left[\mathrm{NO}_{3}^{-}\right]+2\left[\mathrm{H}_{2} \mathrm{O}\right]+4\left[\mathrm{H}^{+}\right] \\
& {\left[\mathrm{Cr}^{\mathrm{III}}\right]_{\mathrm{sed}}^{\downarrow}+4\left[\mathrm{H}^{+}\right]+\left[\mathrm{O}_{2}\right] \underset{k_{-5}}{\stackrel{k_{5}}{\rightleftharpoons}}\left[\mathrm{Cr}^{\mathrm{VI}}\right]_{\uparrow}^{\mathrm{aq}}+2\left[\mathrm{H}_{2} \mathrm{O}\right]}
\end{aligned}
$$

Because $K_{\mathrm{SW}}\left(\mathrm{Cr}^{3+}\right) \gg K_{\mathrm{SW}}\left(\mathrm{CrO}_{4}^{2-}\right)$, the total sediment $\mathrm{Cr}$ concentration is dominated by $\left[\mathrm{Cr}^{3+}\right]$, i.e.,

$$
\left[\mathrm{Cr}_{\mathrm{T}}\right]_{\text {sed }}=\left[\mathrm{Cr}^{3+}\right]_{\text {sed }}+\left[\mathrm{CrO}_{4}{ }^{2-}\right]_{\text {sed }} \approx\left(1+K_{\mathrm{sW}}\right) \cdot\left[\mathrm{Cr}^{3+}\right]_{\mathrm{aq}}
$$

Thus, based on eqs 12 and 13, we characterized the ratio between $\mathrm{CrO}_{4}{ }^{2-}$ and $\mathrm{Cr}^{3+}$ empirically via ${ }^{35}$

$$
\begin{aligned}
& \frac{\left[\mathrm{CrO}_{4}{ }^{2-}\right]_{\mathrm{aq}}}{\left[\mathrm{Cr}^{3+}\right]_{\mathrm{aq}}} \propto \frac{\left[\mathrm{CrO}_{4}{ }^{2-}\right]_{\mathrm{aq}}}{\left[\mathrm{Cr}_{\mathrm{T}}\right]_{\mathrm{sed}}} \\
& \propto \frac{1}{c\left[\mathrm{O}_{2}\right]+d\left[\mathrm{NH}_{4}^{+}\right]+e\left[\mathrm{HPO}_{4}{ }^{2-}+\mathrm{H}_{2} \mathrm{PO}_{4}{ }^{-}\right]+f[\mathrm{pH}]}
\end{aligned}
$$

wherein we take $\left[\mathrm{CrO}_{4}{ }^{2-}\right]_{\text {sed }}$ on average to be $4.13 \%$ of total $\mathrm{Cr}^{91}$ and $c, d, e$, and $f$ are regression coefficients ${ }^{35}$ (Figure S4). 
Table 2. Proton Dissociation Constant $\left(\mathrm{pK}_{\mathrm{a}}\right)$ Values $^{a}$

\begin{tabular}{|c|c|c|c|}
\hline name & formula & $\mathrm{p} K_{\mathrm{a}}$ & ref \\
\hline tetrabutyltinhydroxide & $\mathrm{Sn}(\mathrm{By})_{4}$ & $\mathrm{n} / \mathrm{a}$ & $\mathrm{n} / \mathrm{a}$ \\
\hline tributyltinhydroxide cation & $\left(\mathrm{Sn}\left(\mathrm{OH}_{2}\right)\right)^{+}(\mathrm{By})_{3}$ & 6.25 & $79-81$ \\
\hline dibutyltinhydroxide cation & $\left(\mathrm{Sn}\left(\mathrm{OH}_{2}\right)_{1}\right)^{+}(\mathrm{OH})_{1}(\mathrm{By})_{2}$ & $5.1( \pm 0.2)$ & 82 \\
\hline monobutyltinhydroxide cation & $\left(\mathrm{Sn}\left(\mathrm{OH}_{2}\right)_{1}\right)^{+}(\mathrm{OH})_{2}(\mathrm{By})_{1}$ & $5.9( \pm 0.1)$ & 82 \\
\hline triphenyltinhydroxide cation & $\mathrm{Sn}\left(\mathrm{OH}_{2}\right)^{+}(\mathrm{Ph})_{3}$ & 5.2 & $79,81,83$ \\
\hline diphenyltinhydroxide cation & $\left(\mathrm{Sn}\left(\mathrm{OH}_{2}\right)_{1}\right)^{+}(\mathrm{OH})_{1}(\mathrm{Ph})_{2}$ & 4.0 & $84^{b}$ \\
\hline monophenyltinhydroxide cation & $\left(\mathrm{Sn}\left(\mathrm{OH}_{2}\right)_{1}\right)^{+}(\mathrm{OH})_{2}(\mathrm{Ph})_{1}$ & 4.8 & $* * c$ \\
\hline dihydrogenphosphate & $\mathrm{H}_{2} \mathrm{PO}_{4}^{-}$ & 7.2 & $\mathrm{n} / \mathrm{a}$ \\
\hline ammonia & $\mathrm{NH}_{4}^{+}$ & 9.25 & $\mathrm{n} / \mathrm{a}$ \\
\hline
\end{tabular}

${ }^{a}$ See Table S2 for full details. By $=$ butyl; $\mathrm{Ph}=$ phenyl. ${ }^{b}$ In $75 \%$ dioxane-water solution. $\mathrm{p} K_{\mathrm{a}}$ values of ligands in $75 \%$ dioxane-water solutions are higher than those reported in water. ${ }^{84}{ }^{4}$ Double asterisks mean an estimation assuming the substitution of butyl by phenyl has a constant effect on $\mathrm{p} K_{\mathrm{a}}: \mathrm{p} K_{\mathrm{a} \text { MPT }}=\mathrm{p} K_{\mathrm{a} \text { MBT }}-\left(\left(\mathrm{p} K_{\mathrm{a} \text { TBT }}-\mathrm{p} K_{\mathrm{a} \text { TPT }}\right)+\left(\mathrm{p} K_{\mathrm{a} \text { DBT }}-\mathrm{p} K_{\mathrm{a} \text { DPT }}\right) / 2\right)$.

Since $K_{\mathrm{SW}}$ of $\mathrm{Cr}^{\mathrm{VI}}(<1-50 \mathrm{~L} / \mathrm{kg}) \gg \mathrm{Cr}^{111}(850-5600 \mathrm{~L} / \mathrm{kg}){ }^{92}$ $\sim 90 \%$ of aqueous $\mathrm{Cr}$ is $\mathrm{CrO}_{4}{ }^{2-}$.

2.4. Median Effect Concentrations (EC50). With the exception of $\mathrm{Cr}$ and $\mathrm{Sn}$, we assumed that the total concentration of metals is equal to a single free valent (uncomplexed) $\mathrm{M}^{2+}$ oxidation state, as the sole contributor to the observed toxicity. We assume that $\mathrm{Cr}$ expresses toxicity only via the $\mathrm{CrO}_{4}{ }^{2-}$ form (Table 3).

In contrast to uncomplexed heavy metals (Table 3 ), to our knowledge, there are no 6 day EC50 values available for $H$. incongruens growth when exposed to organotins, $\mathrm{NH}_{3}$, or $\mathrm{H}_{2} \mathrm{PO}_{4}{ }^{-} / \mathrm{HPO}_{4}{ }^{2-}$. Since we assumed all $\mathrm{H}$. incongruens to reside in the water layer, we screened the literature for aqueous

Table 3. H. incongruens Effect Level Concentrations of Chemicals from the Open Literature ${ }^{a}$

\begin{tabular}{|c|c|c|c|}
\hline chemical & $\begin{array}{l}\text { effect (EC50) } \\
\text { concentration } \\
(\mathrm{ng} / \mathrm{L})\end{array}$ & $\begin{array}{c}\text { effect }(\text { EC50) } \\
\text { concentration } \\
(\text { ng/L cation) })^{b}\end{array}$ & ref \\
\hline tetrabutyltin & 50 & $\mathrm{n} / \mathrm{a}$ & $\begin{array}{c}\text { Table } \\
\text { S3 }\end{array}$ \\
\hline tributyltinhydroxide & 50 & 3.5 & $\begin{array}{c}\text { Table } \\
\text { S3 }\end{array}$ \\
\hline dibutyltinhydroxide & 50 & 0.3 & $\begin{array}{c}\text { Table } \\
\text { S3 }\end{array}$ \\
\hline monobutyltinhydroxide & 50 & 1.6 & $\begin{array}{c}\text { Table } \\
\text { S3 }\end{array}$ \\
\hline triphenyltinhydroxide & 50 & 0.3 & $\begin{array}{c}\text { Table } \\
\text { S3 }\end{array}$ \\
\hline diphenyltinhydroxide & 50 & 0.02 & $\begin{array}{c}\text { Table } \\
\text { S3 }\end{array}$ \\
\hline monophenyltinhydroxide & 50 & 0.1 & $\begin{array}{c}\text { Table } \\
\text { S3 }\end{array}$ \\
\hline $\mathrm{Cu}^{2+}$ & 950,000 & $\mathrm{n} / \mathrm{a}$ & 95 \\
\hline $\mathrm{Ni}^{2+}$ & 2500,000 & $\mathrm{n} / \mathrm{a}$ & 95 \\
\hline $\mathrm{Hg}^{2+}$ & 400,000 & $\mathrm{n} / \mathrm{a}$ & 95 \\
\hline $\mathrm{Zn}^{2+}$ & $14,775,880$ & $\mathrm{n} / \mathrm{a}$ & 95 \\
\hline $\mathrm{Cd}^{2+}$ & 70,000 & $\mathrm{n} / \mathrm{a}$ & 95 \\
\hline $\mathrm{CrO}_{4}{ }^{2-c}$ & $4,310,000$ & $\mathrm{n} / \mathrm{a}$ & 95 \\
\hline $\mathrm{Pb}^{2+}$ & $39,200,000$ & $\mathrm{n} / \mathrm{a}$ & 95 \\
\hline $\mathrm{NH}_{3}$ & 2000 & $140,000^{d}$ & 96,97 \\
\hline $\mathrm{HPO}_{4}{ }^{2-} / \mathrm{H}_{2} \mathrm{PO}_{4}^{-}$ & $3,905,460,000$ & $2,000,000,000^{e}$ & 49 \\
\hline
\end{tabular}

${ }^{a_{a}}$ The values for organotins are the means from hatching, developmental, growth, and mortality experiments with varying durations (4 to 28 days); details are shown in Table S3. ${ }^{b}$ Assuming $\mathrm{pH}=7.4{ }^{c}$ Since dichromate hydrolyzes in water $\left(\mathrm{Cr}_{2} \mathrm{O}_{7}{ }^{2-}+\mathrm{H}_{2} \mathrm{O} \rightleftharpoons\right.$ $\left.2 \mathrm{CrO}_{4}{ }^{2-}+2 \mathrm{H}^{+}\right)$, we multiplied EC50 by $2 .{ }^{d}$ Represents $\mathrm{NH}_{3}$. ${ }^{e}$ Represents $\mathrm{HPO}_{4}{ }^{2-}$. phase EC50 values for related species/studies. Though tributylated organotin is generally more toxic than other organotins, ${ }^{93,94}$ to our knowledge, there is no information on the (relative) $H$. incongruens toxicity due to substituents.

Based on Table S3, we initially estimated (based on logaverages) the EC50 of (neutral) organotins, $\mathrm{NH}_{3}$, and $\mathrm{HPO}_{4}^{2-}$ for $H$. incongruens growth to be 50, 2000, and 2,000,000,000 ng/L (Table 3), respectively.

2.5. Toxic Unit (TU). 2.5.1. Initial Approximation. The TU estimates mixture-toxicity risks to both terrestrial and aquatic communities. ${ }^{8}$ We assessed the total exposure from the sediment by summing the exposures for all of the contaminants $(\text { eq } 15)^{98}$

$$
\mathrm{TU}=\sum_{i=1}^{n} \frac{\left[C_{i}\right]_{\mathrm{aq}}}{\gamma_{i}\left[\mathrm{EC} 50_{i}\right]_{\mathrm{aq}}}
$$

wherein $n$ reflects the number of pollutants $i$, taken as heavy metals, organotins, $\mathrm{NH}_{3}$, and $\mathrm{H}_{2} \mathrm{PO}_{4}{ }^{-} / \mathrm{HPO}_{4}{ }^{2-}$.

For the current purpose, it was not feasible to parametrize a priori the toxic interaction between chemicals based on their EC50 values only (i.e., without SSD shape parameters). ${ }^{51,99}$ Taking $\gamma_{i}=1$ reflects all chemicals to have a similar mode of action (MoA) and negligible interaction between chemicals. As the simple response addition (RA) method does not necessarily produce better results than concentration addition (CA), ${ }^{35}$ eq 15 produces an "educated guess" for the TU of $H$. incongruens.

2.5.2. Calibration. Assuming a logistic distribution of sensitivities toward the polluted sediment, we described the percentage of growth inhibited as a function of exposure via a cumulative logistic distribution function ${ }^{98}$

$$
\text { \%growth inhibition }=\frac{100}{1+\mathrm{e}^{-[(\log \mathrm{TU}) / \beta]}}
$$

wherein $\beta$ is a steepness function and TU is initially the ratio of the measured (bioavailable) chemical concentration $[\mathrm{C}]_{\mathrm{aq}}$ to its effect concentration $[\mathrm{EC} 50]_{\mathrm{aq}} \cdot{ }^{100}$ Fitting mortalities with these TU values (Section 2.5.1) produced suboptimal results (Figure 3A; Figures S5, S7).

To acquire statistically better predictions based on the explained variance, we allowed variation in EC50 values to fit the growth inhibition data (Section 2.6) via eq 16. This was done via the factor $\gamma_{i}$ in eq 15. The preselected range for $\gamma_{i}$ was 1000. The fitting implies the average TU fixed at the exposure for which $50 \%$ of the growth is inhibited. We envisioned potential divergences between values for $\gamma_{i} \mathrm{EC50}$ and EC50 to 
be the result of unknown testing procedures and conditions altering speciation, bioavailability (e.g., metals as oxides or organometals), or MoAs. Final $\gamma_{i}$ EC50 values are given in Figure 2.

2.6. Bioassay Description and Data Curation. We calibrate and test our methods (eqs 1-16) using data on whole-sediment toxicity assessed by VMM via laboratory bioassays performed on the ostracod $H$. incongruens, a small benthic freshwater crustacean. The data represents a 6 day growth inhibition test (ISO $\left.14371^{101}\right)$ with freshly $(\leq 52 \mathrm{~h}$ old) hatched cysts (i.e., neonates, with lengths of 150-250 $\mu \mathrm{m})$ incubated at $25( \pm 1){ }^{\circ} \mathrm{C}$, in darkness. Details are shown elsewhere. ${ }^{45,102}$ The percentage \% of growth inhibition $\mu$ because of exposure to sediment is defined ${ }^{45}$ as

\%growth inhibition

$$
=100-\frac{\text { length }_{\text {day6,test }}-\text { length }_{\text {day } 0}}{\text { length }_{\text {day6,reference }}-\text { length }_{\text {day } 0}} \times 100
$$

where the lengths are the averages of a total of 60 organisms distributed across six replicates. The reference refers to a standard sand. For the reference, length $\mathrm{day}_{\text {, reference }} \geq 1.5$. length $_{\mathrm{day} 0}$ and mortality is $\leq 20 \%$. To enlarge our modeling domain, we specifically included also bioassays reporting negative growth inhibition (i.e., growth stimulation).

Since the bioassay is aerobic, it should represent aerobic sediments in the field. This implies minimizing speciationrelated changes due to in situ anaerobic-aerobic transformations. Also, previous $\mathrm{O}_{2}$ deprivation in the field may create bias for germination/growth (chemical cues) at the start of the bioassay: crustaceans are sensitive to $\mathrm{O}_{2}$ deprivation; ${ }^{103,104}$ low $\mathrm{O}_{2}$ induces dormancy $(\mathrm{HOEC}=5.5 \mathrm{mg} \mathrm{O} /$ L). ${ }^{104}$ Taking $44 \pm 4 \mathrm{mg} / \mathrm{L}$ and 0.21 as solubility $\left(T \approx 20^{\circ} \mathrm{C}\right)$ and partial pressure, respectively, this amounts to $60 \pm 5 \% \mathrm{O}_{2}$. $H$. incongruens does not tolerate acidic conditions. ${ }^{39}$

Therefore, we exclude all assays for which the field porewater $\mathrm{O}_{2}<65 \%, \mathrm{O}_{2} \geq 100 \%$, and $\mathrm{pH} \leq 6.5$, which we consider nonrepresentable sediments.

\section{RESULTS}

We performed analyses to elucidate the toxicity of sediments in Flanders to $H$. incongruens. According to initial TU results (Figures S5, S7), $\mathrm{NH}_{3}(\mathrm{TU}=0.1)$ contributed most to $H$. incongruens growth inhibition. Other contributors were $\mathrm{Ni}$ and $\mathrm{Cu}$ (TUs $\leq 0.1)$, whereas the individual TUs of $\mathrm{Zn}, \mathrm{Cd}, \mathrm{CrO}_{4}$, $\mathrm{Hg}$, and $\mathrm{Pb}$ were $\leq 0.01$. Predicting the \% growth inhibition via initial TU using initial (standard) EC50 values (Table 3, Section 2.5.1) yielded maximal explained variance lower than $30 \%$. Initially, speciation calculations (eqs 11, 14) did not appear to improve these results. In contrast to Figure S7 (wherein there is a low contribution), organotins are among the species most highly correlating with $H$. incongruens \% growth inhibition (Figure S9).

We then performed "semiempirical" analyses to further elucidate the toxicity of sediments by letting $\gamma_{i}$ EC50 values fit the growth inhibition data (Section 2.5.2). This "calibrating" procedure allowed a robust TU analysis for $H$. incongruens. According to the semiempirical analysis, too, $\mathrm{NH}_{3}$ dominates the $\mathrm{TU}(\mathrm{TU}=0.3)$. Additional toxic pressure arises from organotins (as represented by tributyltin, $\mathrm{TU}=0.3$ ). Then, the contributions from $\mathrm{Ni}$ and $\mathrm{Cu}$ appear minor $(\leq 0.1)$ (Figure 1$)$. Inclusion of chemicals other than $\mathrm{NH}_{3}, \mathrm{HPO}_{4}{ }^{2-}$, and

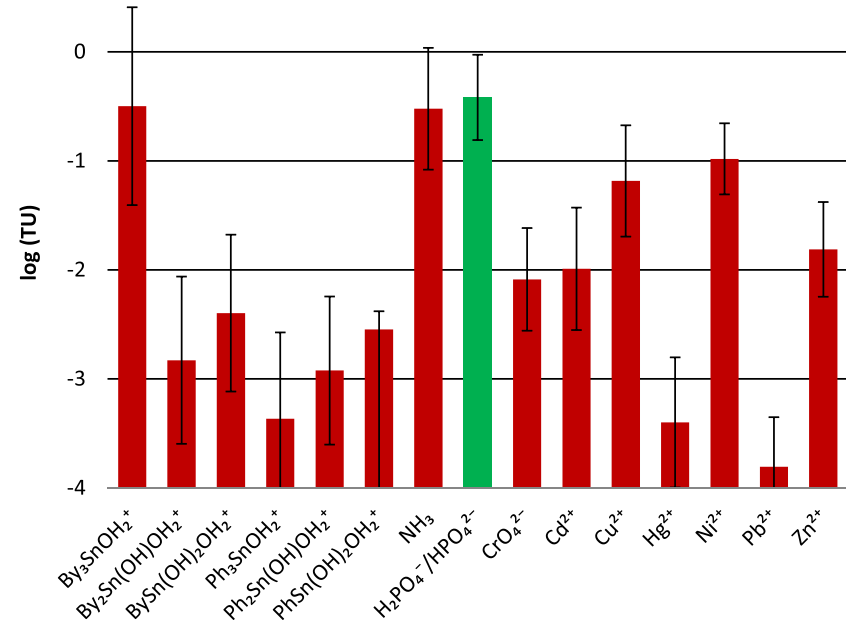

Figure 1. Toxic units for $H$. incongruens $\left([\mathrm{C}]_{\mathrm{aq}} / \mathrm{EC} 0_{\mathrm{aq}}\right)$ for individual pollutants in sediments from water bodies in Flanders. Table 3 denotes $\mathrm{EC50}_{\mathrm{aq}}$ values for free metals; Figure 2 denotes EC50 values for $\mathrm{NH}_{3}, \mathrm{By}_{3} \mathrm{SnOH}_{2}{ }^{+}$, and $\mathrm{H}_{2} \mathrm{PO}_{4} / \mathrm{HPO}_{4}$, contrasting ranges in Table 3. Hence, the TUs may be both underestimations/overestimations. Error bars denote variability throughout Flanders. For MFT $\left(\mathrm{PhSn}(\mathrm{OH})_{2} \mathrm{OH}_{2}^{+}\right)$, assuming porewater $(\mathrm{pH}=7.5), 99 \%$ of samples were below the detection limit (DL); negative errors are 10-fold the $\mathrm{SD}$ including the values set at the DL.

$\mathrm{By}_{3} \mathrm{SnOH}_{2}$ only marginally improved the fit. Instead, we found a positive influence by $\mathrm{HPO}_{4}{ }^{2-}$, i.e., growth-promoting ( TU $=-0.3)$.

After calibration, we found that speciation calculations (eq 11) significantly improved the results (Figure 3B,C). Then, $\mathrm{NH}_{3}$, organotins, and $\mathrm{HPO}_{4}{ }^{2-}$ explain up to $90 \%$ of the observed variance in the $\%$ growth inhibition for water bodies throughout Flanders. We established $\gamma_{i}$ EC50 values for $\mathrm{NH}_{3}$, $\mathrm{HPO}_{4}{ }^{2-}$, and TBT cation $\left(\mathrm{By}_{3} \mathrm{SnOH}_{2}{ }^{+}\right)$at $150,000-39,000$ and $0.003 \mathrm{ng} / \mathrm{L}$. The relative importance of the toxicants differs between water bodies. In general, there is a higher toxic pressure in West Flanders than in inland regions (Table S4). In general, predictions for $H$. incongruens growth inhibition are more precise for "uniform" (e.g., large rivers and canals) water bodies than for small "nonuniform" water bodies.

\section{DISCUSSION}

For sediments in Flanders, we report a maximum growth of $H$. incongruens of $56 \%$ (Supporting Information). The curated data depict a leveling (for low toxicant concentrations) between 0 and $-40 \%$ (Figure 2). In comparison, $H$. incongruens grows in unpolluted soft and hard water $(\mathrm{pH}=$ 7) with $0.063( \pm 0.003)$ and $0.072( \pm 0.003) \mathrm{mm} /$ day, respectively. ${ }^{105}$ Assuming linear growth, this amounts to $84( \pm 42) \%$ in 6 days, similar to sediments in Flanders with "low" toxicant concentrations. This indicates toxic pressure to $H$. incongruens in the majority of bioassays on sediments from Flanders.

We explain up to $90 \%$ of the variance in $H$. incongruens growth. The standard error of model prediction (Figure 2) is lower than that of a similar model for H. azteca. ${ }^{35}$ This is likely related to a better defined testing system and lower physical or metabolic complexity of the organism. ${ }^{13,45}$ Predictions appear more precise for neonate growth than for survival (Figures S9, S13), similar to earlier observations. ${ }^{96}$ A coefficient of variation of $6-20 \%$ was reported using parallel mortality assays. ${ }^{106}$ Thus, the contribution of other toxicants, erroneous 


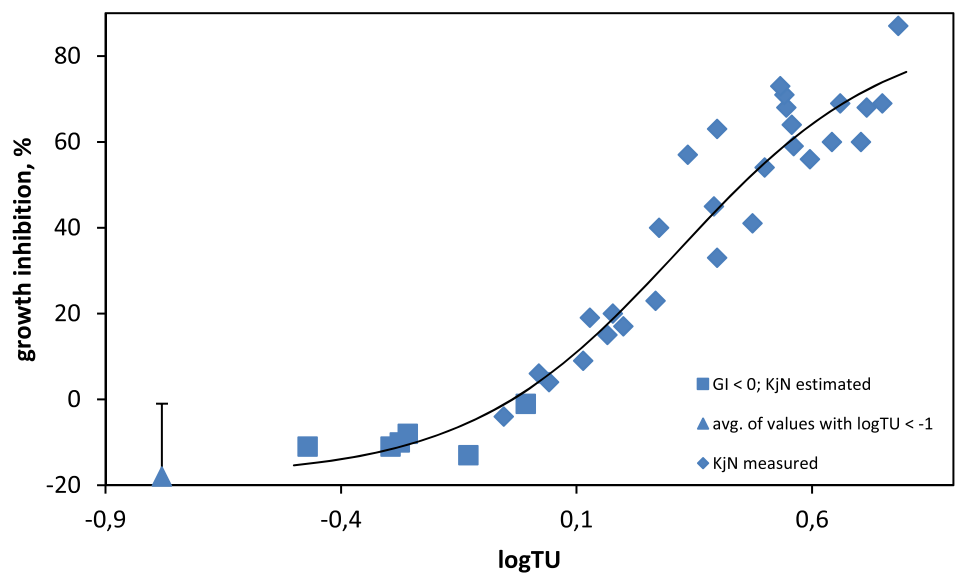

\begin{tabular}{|l|l|l|l|l|l|}
\hline Chemical & coefficient (fit) & $\begin{array}{l}\text { log(average } \\
\text { concentration) }\end{array}$ & $\begin{array}{l}\text { average } \\
\text { concentration } \\
\text { ng/L }\end{array}$ & contribution (\%) & $\gamma_{i} \mathrm{EC50}(\mathrm{ng} / \mathrm{L})$ \\
\hline $\mathrm{NH}_{3}$ & 17.8 & 5.7 & 512,226 & 30.1 & $153,932( \pm 76,966)$ \\
\hline $\mathrm{HPO}_{4}{ }^{2-}$ & -22.6 & 5.0 & 103,904 & 38.2 & $-39,699(27,145-85,840)$ \\
\hline $\begin{array}{l}\mathrm{By} \mathrm{SnOH}_{2}{ }^{+} \\
\mathrm{By} 3 \mathrm{SnOH}\end{array}$ & 18.8 & -2.0 & 0.00998 & 31.7 & $\begin{array}{l}0.0032 \pm 0.0016 \\
0.06( \pm 0.03)\end{array}$ \\
\hline
\end{tabular}

Figure 2. $\mathrm{H}$. incongruens growth inhibition (\%) versus the toxic unit. EC50 for organotin cations was taken to be $0.003 \mathrm{ng} / \mathrm{L}$, representing $\mathrm{By}_{3} \mathrm{SnOH}_{2}{ }^{+}$. Simulation was performed using $\beta=4.5$ (unitless). The far-left triangle denotes the weighted average of values with log TU $<-1$. Squares denote data wherefore $\mathrm{KjN}$ was unknown and taken as a regional average (Section 2.1). The table provides corresponding uncertainties/ ranges. For EC50 values, the errors are those carried over from errors in bioavailabilities.

speciation/bioavailability, or mixture effects to the residual variance $(\sim 10 \%$, Figure 2$)$ is limited. 10-fold intraspecies uncertainty factors are widely used; ${ }^{107}$ our prediction errors are well within this margin.

The average toxic pressure for $H$. incongruens is comparable to that for $\mathrm{H}$. azteca. ${ }^{35}$ Both initial and calibrated TU analyses support our hypotheses that $\mathrm{NH}_{3}$, along with heavy metals, dominates the effects on $H$. incongruens. Meanwhile, in contrast to $H$. azteca, ${ }^{35} \mathrm{CrO}_{4}{ }^{2-}$ did not appear to contribute to the apparent toxicity. The analysis also shows that the mixture of organotins, $\mathrm{NH}_{3}$, and $\mathrm{HPO}_{4}{ }^{2-}$ acts distinctly toward $\mathrm{H}$. incongruens. We interpreted this partially as a bioconcentration effect, which we will explain stepwise below. From its distinct sensitivity and the $90 \%$ explained variance, we deem the $H$. incongruens sediment contact test to be a complementary bioassay to evaluate sediment and water quality.

4.1. Organotins. $\mathrm{Ni}$ and $\mathrm{Cu}$ seemed to only marginally inhibit growth (TUs $\leq 0.1$ ), though heavy metal loading as low as $100 \mu \mathrm{g} / \mathrm{kg}$ affecting aquatic species is generally accepted. ${ }^{108}$ Organotins, as characterized by TBT, appear significantly more toxic to $H$. incongruens than to similar aquatic species in singlesubstance tests (Figure 2, Table S3). This is on average a factor of 1000, irrespective of speciation. In other words, the term $\gamma_{\text {TBT }}$ in eq 15 is $\sim 1 \times 10^{-3}$. Metals react with receptors, enzymes, DNA, protein and lipids or produce structural and functional changes resulting in toxic damage. The toxicant can be a derivative of the parent metal or reactive species (ROS or RNS) from (bio)transformations.

The correlation between TBT cation concentrations and growth inhibition is stronger than for the neutral TBT (Figure 3B,C; Figure S10). Since $H$. incongruens is small, the internal (e.g., cytoplasmic) $\mathrm{pH}$ may be correlated to medium/ porewater $\mathrm{pH} .{ }^{109,110}$ This indicates that growth inhibition is associated with the cation. In contrast, organotin toxicity toward yeast increases with cations < hydroxides < chlorides. ${ }^{111}$ From pH 5.8 to 8.0 , the $K_{\mathrm{OW}}$ of TBT and TPT increased. ${ }^{112,113}$ As it partitions into the lipid fraction of the biomembrane, the neutral (hydrophobic) form is more bioavailable: ${ }^{114}$ uptake and bioconcentration of TBT are higher at $\mathrm{pH} 8.0$ (where neutral ТВТОH predominates) than at $\mathrm{pH} 5.0-6.0 .^{115}$

However, biomembrane-water distribution of the TBT cation exceeds liposome-water distribution, and distribution of the TBT cation exceeds that of the neutral hydroxocomplex. This relates to the cation complexing with ligands and proteins. ${ }^{114}$ This indicates that the high sensitivity of $H$. incongruens growth on organotin as compared to other aquatic species (Figure 2; Table S2) does not arise from nonpolar (baseline) narcosis. ${ }^{116}$ In turn, this implies interactions between the TBT cation and proteins with growth regulation activity. ${ }^{117}$

Endocrine activity of TBT in crustaceans refers to the interactions with the ecdysteroid receptor-retinoid-X receptor dimer (CrcEcR-CrcRXR) complex: ${ }^{48,117,118}$ TBT binds in the electrostatic and neutral areas of CrcRXR. ${ }^{117}$ The ecdysone (nuclear) receptor is responsible for transcriptional regulation of molting, ${ }^{119}$ which is critical for growth of crustaceans accumulating (i.e., "feeding on") phosphate and carbonate. Interaction with vitellogenin and cuticular proteins may cause a second endocrine disruption on the Y-organ-ecdysteroidal endocrine axis and impair growth. ${ }^{117}$

4.2. Phosphate. In contrast to toxicity $\left(\gamma_{\mathrm{PO}_{4}}>0\right)$, phosphate appears to promote $H$. incongruens growth $\left(\gamma_{\mathrm{PO}_{4}}<\right.$ 0 ) (eq 15). The apparent effect level is $\sim 0.04 \mathrm{mg} / \mathrm{L}$, far lower than levels causing toxicity $\left(\sim 2000 \mathrm{mg} / \mathrm{L}^{49}\right)$. Given the aqueous concentration of phosphate in the bioassays, $0.02-2$ $\mathrm{mg} / \mathrm{L}$, and an LC50 value of approximately $3900 \mathrm{mg} / \mathrm{L},{ }^{49}$ toxicity of $\mathrm{HPO}_{4}{ }^{2-}$ to $\mathrm{H}$. incongruens is negligible. $H$. incongruens is one of the only two ostracods wherefore $\mathrm{Ca}^{2+}$ 

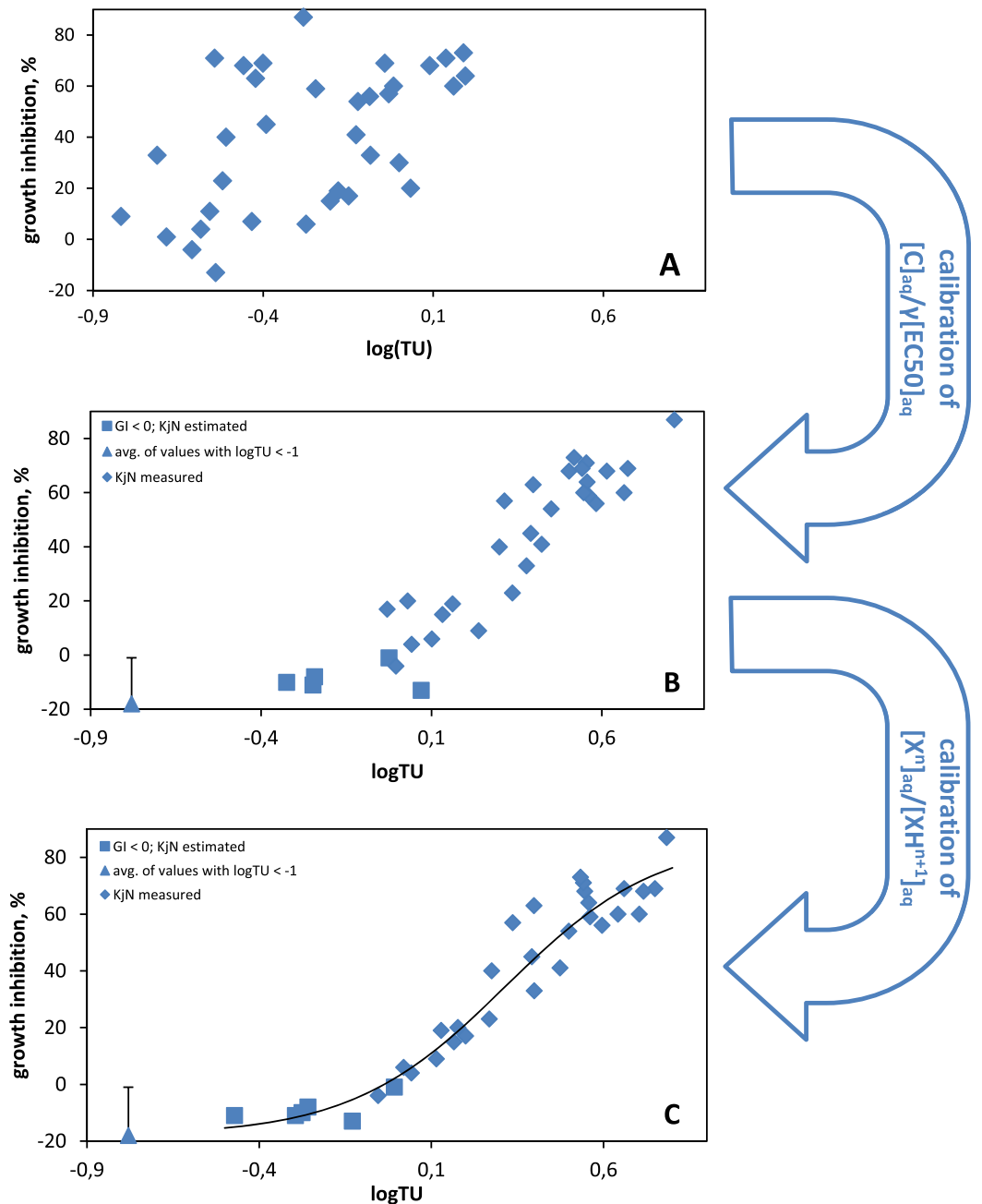

Figure 3. $\mathrm{H}$. incongruens growth inhibition (\%) versus the toxic unit. GI = growth inhibition. (A) EC50 for organotins (cations) represented 3 ng/ $\mathrm{L} ; \mathrm{pH}$ assumed to be 7.5. $R^{2}=0.26$. (B) EC50 for organotins (cations) represented $0.003 \mathrm{ng} / \mathrm{L}$ (eq 17 ); $\mathrm{pH}$ assumed to be 7.5 . $R^{2}=0.82$. $(\mathrm{C})$ EC50 for organotins (cations) represented $0.003 \mathrm{ng} / \mathrm{L}\left(\mathrm{eq} \mathrm{17)} ; \mathrm{pH}\right.$ taken for the porewater. $R^{2}=0.90$.

positively correlates with its natural abundance; $\mathrm{Ca}^{2+}$ associates with phosphate. ${ }^{120} \mathrm{P}$ content of the carapace differs geographically. ${ }^{39}$

Prior to molting, ostracods store $\mathrm{CaHPO}_{4}$ (apatite) granules and chitin precursors in epidermal cells. The granules expulse their content, which is transformed into platelets of $\mathrm{CaCO}_{3}$, disintegrated to amorphous calcite and, ultimately, crystals to build the carapace. ${ }^{121}$ Note that $\mathrm{HCO}_{3}{ }^{-}$is not a limiting factor (relatively constant) since it is added via the synthetic medium. ${ }^{45}$ The carapace may need $\sim 7$ days to complete its calcification, via up to nine growth stages (instars)..$^{50}$

We find a higher correlation for $\mathrm{HPO}_{4}{ }^{2-}$ than for $\mathrm{H}_{2} \mathrm{PO}_{4}{ }^{-}$ (Figure 3B,C; Figure S11). Indeed, an alkaline environment (high $\mathrm{pH}$ ) accelerates tissue calcification. ${ }^{122,123}$ Moreover, calcium phosphate crystallinity decreases with an increase in reaction $\mathrm{pH}^{123,124}$ and solubilities decrease with increasing $\mathrm{pH}^{125}$ The combined results indicate that phosphate in bioassays performed with sediments from Flanders, in the $\mathrm{HPO}_{4}{ }^{2-}$ form, promotes $H$. incongruens growth.

4.3. Ammonia. Whereas we initially assigned an EC50 value for $\mathrm{NH}_{3}$ of $0.002 \mathrm{mg} / \mathrm{L}$, we found an empirical value for $\gamma_{\mathrm{NH}_{3}}$ EC50 of $0.15 \mathrm{mg} / \mathrm{L}$ (implying $\gamma_{\mathrm{NH}_{3}}>1$ ) (eq 15). In analogy, the LC50 value for $H$. azteca exposed to $\mathrm{NH}_{3}$ is $2-5$ $\mathrm{mg} / \mathrm{L},{ }^{78,126}$ whereas in bioassays, it appears empirically to be
$5000 \mathrm{mg} / \mathrm{L}^{35}$ The average $\mathrm{TU}$ of $\mathrm{NH}_{4}{ }^{+} / \mathrm{NH}_{3}$ is 0.3 across Flanders, and $\mathrm{NH}_{3}$ explains $30 \%$ of the variance in growth inhibition. We noted a relatively high toxicity of sediments from West Flanders (e.g., Yser river) collected during (fertilization ${ }^{56}$ in) spring; levels of $\mathrm{NH}_{4}^{+} / \mathrm{KjN}$ in the Yser are structurally high (Table S4); anaerobic conditions are more likely for those sediments.

We found a slightly higher correlation for $\mathrm{NH}_{3}$ than for $\mathrm{NH}_{4}^{+}$(Figure 3B,C; Figure S12). Aquatic ecotoxicity studies in the 1990s identified $\mathrm{NH}_{4}^{+} / \mathrm{NH}_{3}$ (esp. $\mathrm{NH}_{3}$ ) as a contributing cause. ${ }^{127}$ More so than $\mathrm{NH}_{4}{ }^{+}, \mathrm{NH}_{3}$ can pass through biological surfaces into tissue fluid. When $\mathrm{pH}$ of the tissue fluid is lower than that of the surrounding water, $\mathrm{NH}_{3}$ can disrupt ionoregulatory functions. ${ }^{49,128}$ In addition, $\mathrm{NH}_{3}$ may activate $\mathrm{N}$-methyl-D-aspartate receptors in the brain, ${ }^{129}$ leading to intoxication.

4.4. Mixture Effects. The $\gamma_{i} \mathrm{EC}_{5} 0_{i}$ values for $\mathrm{HPO}_{4}{ }^{2-}$, $\mathrm{NH}_{3}$, and organotin used for the analysis differed from the initial estimation (Table 3; Figure 2). With respect to literature EC50 values, much variation exists (Table S3); the values obtained represent extreme values. Thus, the extreme $\gamma_{i} \mathrm{EC50}_{i}$ values may not only represent a direct mode of toxic action from $\mathrm{HPO}_{4}{ }^{2-}, \mathrm{NH}_{3}$, and organotin individually but also 
suggest toxicity as the result of interaction(s) between them, i.e., $\gamma_{i} \neq 1$ (see eq 15$)$.

There are many documented interactions between $\mathrm{P}, \mathrm{N}$, and metals. ${ }^{130}$ However, models (e.g., the TU, eq 15) often describe toxicity additively or independently, ${ }^{98}$ i.e., not including synergistic/antagonistic mixture effects. ${ }^{131}$ Mixture toxicity entails detailed description of the interactions between sediment fractions and chemicals: depending on numerous conditions, metals form organic complexes or oxides, each with its own characteristic influence on the intoxication pathway.

4.4.1. Phosphorus-Tin Interaction. Though phosphorus can be toxic, ${ }^{132}$ it can diminish metal toxicity via precipitation. ${ }^{133}$ Phosphate is a polydentate ligand forming negatively charged complexes with triorganotins mono- and dimers; ${ }^{73,134}$ organotin is $10^{2}-10^{5}$ times more selective toward phosphate than toward other oxoanions ${ }^{135}$ and aids in its extraction. ${ }^{136}$ In fact, extraction of organotins from sediment co-extracts phosphorus compounds. ${ }^{137}$ Plants absorb phosphate; ostracods feed on dead/living plants. Thus, the influence of sediment's organic phosphate on the distribution of TBT in ostracods may relate to dietary assimilation via periphyton. ${ }^{120,130}$ Acute toxicity of TPT on ostracods may be supplemented by elimination of food. ${ }^{138}$

Prominently, $H$. incongruens accumulates $\mathrm{HPO}_{4}{ }^{2-}$, hence TBT, via molting (Section 4.2). Additionally, the $\mathrm{TPT}^{+}$cation sorbs onto liposomes via complex formation with phospholipids. ${ }^{114}$ Guanosine-5-monophosphate (G-5-MP) most efficiently forms a competitive organotin complex; ${ }^{139}$ as an essential enzyme for cell growth, G-5-MP kinase converts GMP to GDP. Combined, the interactions with phosphate compounds indicate an effective bioconcentration larger than based on the thermodynamic (hydrophobic) maximum $((1)$ in Figure 4). Reported BCFs for species (e.g., bivalves) capable of accumulating phosphate are $\sim 1000$ times larger than those without the capability. ${ }^{81,140}$ This value matches with $1 / \gamma_{\text {TBT }}$, insinuating a similar TMoA:



Figure 4. Simplified schematic of interactions between sediment constituents affecting bioassay toxicity. Green and red arrows denote positive and negative effects on $H$. incongruens growth, respectively. According to de Deckere et al., ${ }^{13} \mathrm{O}_{2}$ ought to remain $\geq 60 \%$ during bioassays.



4.4.2. Nitrogen-Tin Interaction. Since the bioassays are aerobic, ${ }^{45,102} \mathrm{NH}_{3} / \mathrm{NH}_{4}$ may be converted to $\mathrm{NO}_{2}^{-} / \mathrm{NO}_{3}{ }^{-}$ (Figure 4), which would be enhanced by bioturbation. ${ }^{74}$ Conversion to $\mathrm{NO}_{3}{ }^{-35}$ could contribute to the high apparent $\gamma$ EC50 value of $\mathrm{NH}_{3}$ (Figure 2). Though affecting ostracods, ${ }^{141-143} \mathrm{NO}_{3}{ }^{-}$is likely not directly toxic. ${ }^{35,144}$ Instead, metal-nitrates are well-soluble, hence bioavailable. ${ }^{145}$ Heavy metals may influence nitrification. ${ }^{88,146}$ In turn, nitrification and volatilization $\left(\mathrm{NH}_{4}^{+} \rightarrow \mathrm{NH}_{3}(\uparrow)+\mathrm{H}^{+}\right)$affect $\mathrm{pH}$. Changes in $\mathrm{pH}$ in sediment/ecotoxicity tests are reported; ${ }^{35,147}$ we cannot assume that buffering was consistent.

Surplus $\mathrm{H}^{+}$increases the cation concentration and interactions of the TBT metal-type behavior by complex formation with ligands in phospholipids and proteins, ${ }^{48,148}$ illustrated by (2) in Figure 4. $\mathrm{NO}_{3}{ }^{-}$and $\mathrm{SO}_{4}{ }^{2-}$ (also in the EPA medium) may solubilize organotins. In addition, the relative concentrations of $\mathrm{NH}_{4}$ and metals may influence uncoupling of mitochondrial oxidative phosphorylation. ${ }^{149}$

4.5. Limitations, Recommendations, and Outlook. Sorption to varying organic carbon did not appear to strengthen correlations (eq 6). Apart from those considered here, other sediment constituents (e.g., $\mathrm{Al}, \mathrm{Mg}, \mathrm{Ca}, \mathrm{S}$ ) affect speciation and bioavailability. ${ }^{30,150}$ Prominently, acid-volatile sulfide (AVS) $)^{20,69}$ relates to invertebrate toxicity. ${ }^{85,86,151} \mathrm{We}$ can determine bioavailability more comprehensively by distinguishing sediment fractions (e.g., humic $\operatorname{acid}^{75}$ ) and binding mechanisms, ${ }^{152}$ pending available data. ${ }^{75,153}$ Section S3 contains a more complete discussion of limitations. Despite increased monitoring, ${ }^{13}$ it is laborious to measure all such relevant parameters, which depend on the sediment/organism. Even if we have such direct detailed information, it is difficult to describe all interactions explicitly. ${ }^{154-156}$ We therefore ought to consider also (semi)empirical- and evidence-based approaches.

Based on the current study, we argue for an approach based on (bio)chemical interactions between $\mathrm{NH}_{4}^{+}$, organotins, and $\mathrm{HPO}_{4}{ }^{2-}$. Incomplete monitoring data for $\mathrm{N}$ or $\mathrm{P}$ might obscure or underestimate ostracod toxicities. ${ }^{35}$ Since phosphate was not present in reference sediments, this may obscure the toxic effect on the ostracods. Thus, we propose to standardize total phosphorus (i.e., phosphate) in the sediment bioassays. Prediction of ostracod growth is probably more straightforward than that of mortality, which relates to, e.g., complexity of the toxic mode of action. Due to the higher sensitivity of juveniles, we recommend using the neonate test or making age-based extrapolations. BCF tests should elucidate the validity of eq 18 .

Pollutants are not always (directly) measured, which would be important for remote (small) water bodies where an "exotic" chemical may skew local toxicity. More direct data for $\mathrm{NH}_{4} / \mathrm{PO}_{4}$ may help to solidify the relationships. ${ }^{35,157,158}$ Large, uniform water bodies are less susceptible to pressures from point releases of chemicals (dilution). Higher temperature and drought (concentrating pollutants) may influence (bio)transformation, $\mathrm{O}_{2}$ uptake, and elevate toxicity. ${ }^{159}$ This determines parametrization, representability, and implementability of models. We may optimize via identifying "hotspot" locations, e.g., bridges/harbors. ${ }^{160}$ Concentrations of organotins appear to decrease over time in sediment in Flanders. Removal mechanisms include leaching into sea or biodegradation (Figure S3; Figure 5), which need to be elucidated. 


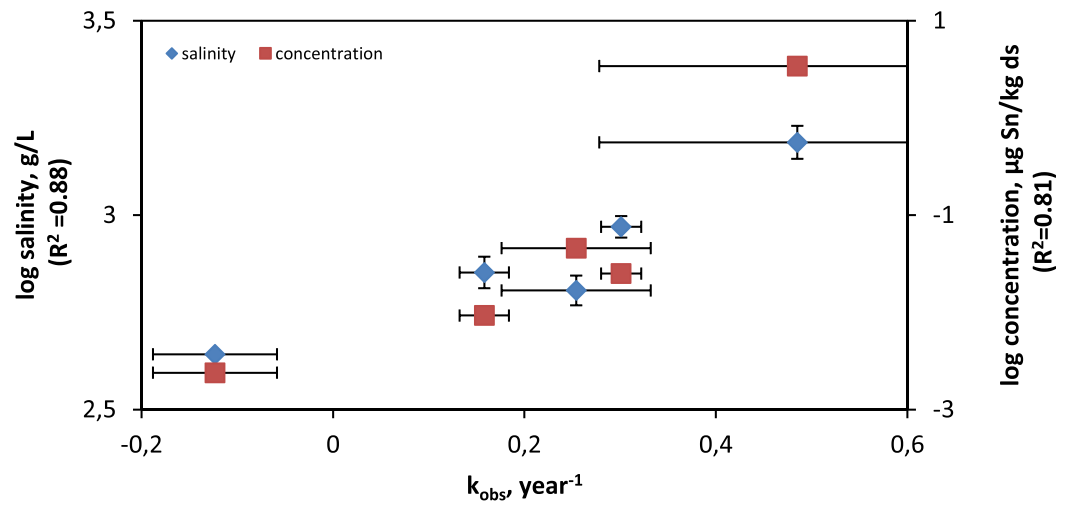

Figure 5. First-order disappearance rate constant for TBT in Flemish sediment ( $x$, in year $\left.{ }^{-1}\right)$ versus salinity and concentration $(y 1$ and $y 2)$. Symbols denote distinct sampling locations, having a uniform temporal trend in concentration (continuously increasing or continuously decreasing).

In this study, we have applied explicit descriptions to characterize the speciation and bioavailability of pollutants in ostracod bioassays performed using sediments from Flanders. Semiempirical toxic unit analyses elucidated the effects of heavy metals (esp. organotin) and ammonia inhibiting $H$. incongruens growth. Based on standard approaches, $26 \%$ of the variance in the observed effect could be explained. Yet, by acknowledging speciation and interactions between bioassay constituents, we can explain up to $90 \%$. Organotin and ammonia appear more and less toxic, respectively, than what is reported in the existing literature for controlled (singlesubstance) laboratory tests. We can attribute this to a cascade of bio-physicochemical interactions affecting speciation and transformations of the chemicals in situ. Prominently, organotins appear to bioaccumulate during the molting process of $H$. incongruens. Future modeling ought to focus on the factors controlling the interactions, via more explicit measurement and monitoring of speciation and bioavailability. This is likely to help in bridging the gap between laboratory and field tests so as to enable a more reliable risk assessment for sediments. Despite the need for further study, we deem our model a worthwhile complementary method to evaluate sediments in Flanders. Applying the approach to more spatiotemporal and geochemical settings ${ }^{11,161}$ will evaluate its broader applicability. Thus, we deem it a starting point for more integrated ecotoxicity modeling in general.

\section{ASSOCIATED CONTENT}

\section{s! Supporting Information}

The Supporting Information is available free of charge at https://pubs.acs.org/doi/10.1021/acs.est.0c02855.

Figure S1: VMM monitoring network for sediment quality assessment. Table S1: Mean characteristics and chemical concentration of sediment samples in Flanders and its three main rivers. Figure S2: Trend of the monthly maximum ammonia concentration. Figure S3: Concentrations of ammonia throughout Flanders. Table S2: Proton dissociation constants $\left(\mathrm{p} K_{\mathrm{a}}\right)$ values. Table S3: Experimental $H$. incongruens effect concentrations (EC) of chemicals. Figure S4: Total concentration of chromium in sediment (as predicted from metal concentrations, so to prevent bias) versus MLR results using \%clay, \%OS, $\mathrm{KjN}, \mathrm{O}_{2}, \mathrm{P}_{\mathrm{T}}$, and $\mathrm{pH}$ as input. Figure S5: \% growth inhibition of $H$. incongruens versus the TU before empirical calibration. Figure S6: \% growth inhibition of $H$. incongruens versus the TU after empirical calibration. Figure S7: H. incongruens toxic units for different chemicals. Figure S8: $H$. incongruens toxic units for different chemicals. Table S4: Aqueous concentrations of chemicals and corresponding toxic units (TUs) calculated. Figure S9: Correlation coefficients between chemicals, bioassays, and sediment characteristics Figure S10: Calculation of TBT cation concentration at $\mathrm{pH}$ 7.5. Figure S11: Calculation of $\mathrm{HPO}_{4}{ }^{2-}$ concentrations at $\mathrm{pH}$ 7.5. Figure S12: Calculation of the $\mathrm{NH}_{3}$ concentration at $\mathrm{pH}$ 7.5. Figure S13: Ostracod mortality (\%) versus ostracod growth inhibition (PDF)

\section{AUTHOR INFORMATION}

\section{Corresponding Author}

Tom M. Nolte - Department of Environmental Science, Institute for Water and Wetland Research, Radboud University

Nijmegen, 6500 GL Nijmegen, the Netherlands; 이이.org/ 0000-0001-8083-0749; Email: t.nolte@science.ru.nl, tom.m.nolte@gmail.com

\section{Authors}

Ward De Cooman - Flanders Environment Agency (VMM), B9300 Aalst, Belgium

Jos P. M. Vink - Unit Soil and Subsurface Systems, Deltares, 3508 AL Utrecht, the Netherlands

Raf Elst - Flanders Environment Agency (VMM), B-9300 Aalst, Belgium

Els Ryken - Flanders Environment Agency (VMM), B-9300 Aalst, Belgium

Ad M. J. Ragas - Department of Environmental Science, Institute for Water and Wetland Research, Radboud University Nijmegen, 6500 GL Nijmegen, the Netherlands

A. Jan. Hendriks - Department of Environmental Science, Institute for Water and Wetland Research, Radboud University Nijmegen, 6500 GL Nijmegen, the Netherlands

Complete contact information is available at:

https://pubs.acs.org/10.1021/acs.est.0c02855

\section{Notes}

The authors declare no competing financial interest.

\section{ACKNOWLEDGMENTS}

"Sullied Sediments" has been co-funded by the European Regional Development Fund through the Interreg VB North 
Sea Region Programme with a grant of 2,043,413 euros with equivalent match funding from the partners involved. The project partnership includes public, private, and third sector organizations based in the United Kingdom, Germany, Belgium, and the Netherlands. We thank the reviewers for their thoughtful comments and efforts that helped us to improve our manuscript.

\section{REFERENCES}

(1) Vandecasteele, B.; De Vos, B.; Tack, F. M. G. Heavy metal contents in surface soils along the Upper Scheldt river (Belgium) affected by historical upland disposal of dredged materials. Sci. Total Environ. 2002, 290, 1-14.

(2) European Environmental Agency Heavy metal emissions: Fig. 1 Trends in emissions of heavy metals (EEA-33). Prod: IND-171-en (AIR 001). https://www.eea.europa.eu/data-and-maps/indicators/eea32heavy-metal-hm-emissions-1/assessment- 10 .

(3) de Souza Machado, A. A.; Spencer, K.; Kloas, W.; Toffolon, M.; Zarfl, C. Metal fate and effects in estuaries: A review and conceptual model for better understanding of toxicity. Sci. Total Environ. 2016, $541,268-281$.

(4) Brils, J. Sediment monitoring and the European Water Framework Directive. Ann Ist Super Sanita 2008, 44, 218-223.

(5) Zoppini, A.; Ademollo, N.; Amalfitano, S.; Casella, P.; Patrolecco, L.; Polesello, S. Organic priority substances and microbial processes in river sediments subject to contrasting hydrological conditions. Sci. Total Environ. 2014, 484, 74-83.

(6) Teuchies, J.; Bervoets, L.; Cox, T. J. S.; Meire, P.; de Deckere, E. The effect of waste water treatment on river metal concentrations: removal or enrichment? J. Soils Sediments 2011, 11, 364-372.

(7) European Community. Directive 2000/60/EC of the European Parliament and the council of 23 October 2000 establishing a framework for Community action in the field of water policy. Official Journal of the European Community 2000, L 327, 1-73.

(8) de Zwart, D.; Posthuma, L.; Gevrey, M.; von der Ohe, P. C.; de Deckere, E. Diagnosis of ecosystem impairment in a multiple-stress context-how to formulate effective river basin management plans. Integr. Environ. Assess. Manage. 2009, 5, 38-49.

(9) Chapma, P. M.; Ho, K. T.; Munns, W. R., Jr.; Solomon, K.; Weinstein, M. P. Issues in sediment toxicity and ecological risk assessment. Mar. Pollut. Bull. 2002, 44, 271-278.

(10) Davoren, M.; Shúilleabháin, S. N.; O’Halloran, J.; Hartl, M. G. J.; Sheehan, D.; O’Brien, N. M.; van Pelt, F. N. A. M.; Mothersill, C. A test battery approach for the ecotoxicological evaluation of estuarine sediments. Ecotoxicology 2005, 14, 741-755.

(11) Hiki, K.; Tobino, T.; Nakajima, F.; Tsukahara, K. Duration of life-cycle toxicity tests with the ostracod Heterocypris incongruens. Environ. Toxicol. Chem. 2017, 36, 3443-3449.

(12) Chapman, P. M.; Anderson, J. A decision-making framework for sediment contamination. Integr Environ Assess Manag 2005, 1, $163-173$.

(13) de Deckere, E.; de Cooman, W.; Florus, M.; DevroedeVanderlinden, M. A manual for the assessment of sediments in Falnders with the TRIAD approach. Ministery of the Flemish Community, Brussels 2000.

(14) Hutchinson, T. H.; Solbe, J.; Kloepper-Sams, P. J. Analysis of the ecetoc aquatic toxicity (EAT) database III - Comparative toxicity of chemical substances to different life stages of aquatic organisms. Chemosphere 1998, 36, 129-142.

(15) Vaal, M. A.; Van Leeuwen, C. J.; Hoekstra, J. A.; Hermens, J. L. M. Variation in Sensitivity of Aquatic Species to Toxicants: Practical Consequences for Effect Assessment of Chemical Substances. Environ. Manage. 2000, 25, 415-423.

(16) Martín, F.; Escoto; Fernández, J.; Fernández, E.; Arco, E.; Sierra, M.; Dorronsoro, C. Toxicity Assessment of Sediments with Natural Anomalous Concentrations in Heavy Metals by the Use of Bioassay. Int. J. Chem. Eng. 2010, 2010, 1-6.
(17) Rämö, R. A.; van den Brink, P. J.; Ruepert, C.; Castillo, L. E.; Gunnarsson, J. S. Environmental risk assessment of pesticides in the River Madre de Dios, Costa Rica using PERPEST, SSD, and msPAF models. Environ. Sci. Pollut. Res. 2018, 25, 13254-13269.

(18) Shirani, M.; Afzali, K. N.; Jahan, S.; Strezov, V.; SoleimaniSardo, M. Pollution and contamination assessment of heavy metals in the sediments of Jazmurian playa in southeast iran. Nat. Sci. Rep. 2020, 10,1

(19) Hsu, L. C.; Huang, C. Y.; Chuang, Y. H.; Chen, H. W.; Chan, Y. T.; Teah, H. Y.; Chen, T. Y.; Chang, C. F.; Liu, Y. T.; Tzou, Y. M. Accumulation of heavy metals and trace elements in fluvial sediments received effluents from traditional and semiconductor industries. Nat. Sci. Rep. 2016, 6, 34250.

(20) Hansen, D. J.; Berry, W. J.; Boothman, W. S.; Pesch, C. E.; Mahony, J. D.; Di Toro, D. M.; Robson, D. L.; Ankley, G. T.; Ma, D.; Yan, Q. Predicting the toxicity of metal-contaminated field sediments using interstitial concentration of metals and acid-volatile sulfide normalizations. Environ. Toxicol. Chem. 1996, 15, 2080-2094.

(21) Oguma, A. Y.; Klerks, P. L. Comparisons Between Laboratory Sediment Toxicity Test Results and Assessment of Benthic Community Changes for a Lake with Mild Metal Contamination. Arch. Environ. Contam. Toxicol. 2019, 78, 106.

(22) Brix, K. V.; Gerdes, R. M.; Adams, W. J.; Grosell, M. Effects of copper, cadmium, and zinc on the hatching success of brine shrimp (Artemia franciscana). Arch. Environ. Contam. Toxicol. 2006, 51, 580583.

(23) Vane, C. H.; Tumer, G. H.; Chenery, S. R.; Richardson, M.; Cave, M. C.; Terrington, R.; Gowing, C. J. B.; Moss-Hayes, V. Trends in heavy metals, polychlorinated biphenyls and toxicity from sediment cores of the inner River Thames estuary, London, UK. Environ. Sci.: Processes Impacts 2020, 22, 364-380.

(24) Parrott, J. L.; Raine, J. C.; McMaster, M. E.; Hewitt, L. M. Chronic toxicity of oil sands tailings pond sediments to early life stages of fathead minnow (Pimephales promelas). Heliyon 2019, 5, No. e02509.

(25) Barrera Herrera, J. A.; Espinosa, A. J.; Álvarez, J. P. Pollution in Lago de Tota, Colombia: acute toxicity on Daphnia magna (Cladocera: Daphniidae) and Hydra attenuata (Hydroida: Hydridae). Rev. Biol. Trop. 2019, 67, 11-23.

(26) Babić, S.; Barišić, J.; Stipaničev, D.; Repec, S.; Lovrić, M.; Malev, O.; Martinović-Weigelt, D.; Čož-Rakovac, R.; Klobučar, G. Assessment of river sediment toxicity: Combining empirical zebrafish embryotoxicity testing with in silico toxicity characterization. Sci. Total Environ. 2018, 643, 435-450.

(27) Besser, J. M.; Steevens, J.; Kunz, J. L.; Brumbaugh, W. G.; Ingersoll, C. G.; Cox, S.; Mebane, C.; Balistrieri, L.; Sinclair, J.; MacDonald, D. Characterizing toxicity of metal-contaminated sediments from the Upper Columbia River, Washington, USA, to benthic invertebrates. Environ. Toxicol. Chem. 2018, 37, 3102-3114.

(28) Long, E. R.; Macdonald, D. D.; Smith, S. L.; Calder, F. D. Incidence of Adverse Biological Effects within Ranges of Chemical Concentrations in Marine and Estuarine Sediments. Environ. Manage. 1995, 19, 81-97.

(29) Vink, J. P. M. The origin of speciation: Trace metal kinetics over natural water/sediment interfaces and the consequences for bioaccumulation. Environ. Pollut. 2009, 157, 519-527.

(30) Bootsma, H. P.; Vink, J. P. M. Simple equations for the calculation of free metal ion activities in natural surface waters 2016.

(31) Van den Bril, B.; Meremans, D.; Roekens, E. A Monitoring Network on Acidification in Flanders, Belgium. Sci. World J. 2011, 11, $2358-2363$

(32) Vannevel, R.; Brosens, D.; De Cooman, W.; Gabriels, W.; Lavens, F.; Mertens, J.; Vervaeke, B. The inland water macroinvertebrate occurrences in Flanders, Belgium. Zookeys 2018, 759, $117-136$.

(33) VLM eindrapport "milieukundig en economisch verantwoord fosforgebruik"; APLM/2014/3 in opdracht van VLM /29.01.2019: 2019. 
(34) Struyf, D. voortgangsrapport Mestbank 2010 over het mestbeleid in vlaanderen; 2010.

(35) Nolte, T. M.; De Cooman, W.; Vink, J.P.; Hendriks, A. J., Nitrogen-chromium interactions driving Hyalella azteca mortality when exposed to Flanders' sediments. under review 2020.

(36) Hunting, E. R.; de Jong, S.; Vijver, M. G. Assessment of monitoring tools and strategies safeguarding aquatic ecosystems within the European water framework directive; CML-rapport 192, ISBN: 978-905191-182-4; Leiden, 2017.

(37) de Paiva Magãlhaes, D.; da Costa Marques, M. R.; Baptista, D. F.; Buss, D. F. Selecting a sensitive battery of bioassays to detect toxic effects of metals in effluents. Ecotoxicol. Environ. Saf. 2014, 110, 7381.

(38) Bondarenko, O. M.; Heinlaan, M.; Sihtmäe, M.; Ivask, A.; Kurvet, I.; Joonas, E.; Jemec, A.; Mannerström, M.; Heinonen, T.; Rekulapelly, R.; Singh, S.; Zou, J.; Pyykkö, I.; Drobne, D.; Kahru, A. Multilaboratory evaluation of 15 bioassays for (eco)toxicity screening and hazard ranking of engineered nanomaterials: FP7 project NANOVALID. Nanotoxicology 2016, 10, 1229-1242.

(39) Ruiz, F.; Abad, M.; Bodergat, A. M.; Carbonel, P.; RodríguezLázaro, J.; González-Regalado, M. L.; Toscano, A.; García, E. X.; Prenda, J. Freshwater ostracods as environmental tracers. Int. J. Environ. Sci. Technol. 2013, 10, 1115-1128.

(40) Gruiz, K.; Molnar, M. Aquatic toxicology. In Engineering Tools for Environmental Risk Management: 2. Environmental Toxicology, 1st. ed.; Gruiz, K.; Meggyes, T.; Fenyvesi, E., Ed.; CRC Press: 2015; 168. (41) De Cooman, W.; Blaise, C.; Janssen, C.; Detemmerman, L.; Elst, R.; Persoone, G. History and sensitivity comparison of two standard whole-sediment toxicity tests with crustaceans: the amphipod Hyalella azteca and the ostracod Heterocypris incongruens microbiotest. Knowledge and Management of Aquatic Ecosystems 2015, $416,15$.

(42) Mercury threat in industrially impacted surface water bodies in Romania - integrated approach (MERCURO). SNSF/UEFISCDI 2014.

(43) Becouze-Lareure, C.; Bazin, C.; Namour, P.; Breil, P.; Perrodin, Y. Multi-Level Approach of the Ecotoxicological Impact of a Combined Sewer Overflow on a Peri-Urban Stream. J Water Resour. Prot. 2012, 984-992.

(44) Wolska, L.; Namiesnik, J.; Michalska, M.; Bartoszewicz, M. Preliminary Study on Toxicity of Aquatic Ecosystems in Bug River Basin. Pol. J. Environ. Stud. 2008, 17, 811-816.

(45) MicroBioTests, OSTRACODTOXKIT F: "Direct contact" Toxicity Test for Freshwater Sediments Standard Operating Procedure V071211. Gent, Belgium.

(46) Vogt, É. L.; Model, J. F. A.; Vinagre, A. S. Effect of Organotins on Crustaceans: Update and Perspective. Front. Endocrinol. 2018, 9, 65.

(47) Alzieu, C.; Michel, P. L'etain et les organoétains en milieu marin: biogéochimie et ecotoxicologie. Repères Océan, Edit IFREMER 1998, 15, 104

(48) Parmentier, K. F. V.; Verhaegen, Y.; De Witt, B. P.; Hoffman, S.; Delbare, D. H. R.; Roose, P. M.; Hyiland, K. D. E.; Burgeot, T.; Smagghe, G. J.; Cooreman, K. Tributyltin: A Bottom-Up Regulator of the Crangon crangon Population? Front. Mar. Sci. 2019, 6, 633.

(49) Yu, N.; Chen, S.; Li, E.; Chen, J.; Chen, L. Tolerance of Physocypria kraepelini (Crustacean, Ostracoda) to water-borne ammonia, phosphate and $\mathrm{pH}$ value. J. Environ. Sci. 2009, 21, 15751580.

(50) Karanovic, I. Recent Freshwater Ostracods of the World: Crustacea, Ostracoda, Podocopida; Springer: Heidelberg, 2012.

(51) Hendriks, A. J. Modeling Response of Species to Microcontaminants - Comparative Ecotoxicology by (Sub)Lethal Body Burdens as a Function of Species Size and Partition Ratio of Chemicals. Ecotoxicol. Environ. Saf. 1995, 32, 103-130.

(52) Hutchinson, G. E. A treatise on limnology - geography, physics, and chemistry; Wiley \&Sons: 1957; 1 .
(53) van Beusekom, J. E. E.; de Jonge, V. N. Long-term changes in Wadden Sea nutrient cycles: importance of organic matter import from the North Sea. Hydrobiologia 2002, 475, 185-194.

(54) Cheng, X.; Zeng, Y.; Guo, Z.; Zhu, L. Diffusion of Nitrogen and Phosphorus Across the Sediment-Water Interface and In Seawater at Aquaculture Areas of Daya Bay, China. Int. J. Environ. Res. Public Health 2014, 11, 1557-1572.

(55) Serajuddin, M.; Chowdury, A.; Hussain, M. Increasing Level of Ammonia in the Surface Raw Water Source at Dhaka, Bangladesh. Pollution 2018, 4, 211-225.

(56) Departement Landbouw en Visserij PRAKTIJKGIDS BEMESTING Grasland en voedergewassen 28.01.2016; Van Liefferinge, J., 2016.

(57) Hendriks, C.; Kranenburg, R.; Kuenen, J. J. P.; Van den Bril, B.; Verguts, V.; Schaap, M. Ammonia emission time profiles based on manure transport data improve ammonia modelling across north western Europe. Atmos. Environ. 2016, 131, 83-96.

(58) Van den Broeck, D. H. M.; Verbeylen, G.; Jacobs, I.; Van Dorsselaer, P. Korstmossen als bio-indicator voor ammoniakconcentraties (Eindrapport); Rapport 2009/5; Mechelen, België, 2009.

(59) EPA Ecological Effects Test Guidelines. OPPTS 850.1735 Whole Sediment Acute Toxicity Invertebrates Freshwater; 1996.

(60) Van Der Kooij, L. A.; Van De Meent, D.; Van Leeuwen, C. J.; Bruggeman, W. A. Deriving quality criteria for water and sediment from the results of aquatic toxicity tests and product standards: Application of the equilibrium partitioning method. Water Res. 1991, $25,697-705$.

(61) Tebes-Stevens, C. L.; Jones, W. J. Estimation of microbial reductive transformation rates for chlorinated benzenes and phenols using a quantitative structure-activity relationship approach. Environ. Toxicol. Chem. 2004, 23, 1600-1609.

(62) Mackin, J. E.; Aller, R. C. Ammonium Adsorption in MarineSediments. Limnol. Oceanogr. 1984, 29, 250-257.

(63) Van Raaphorst, W.; Malschaert, J. F. P. Ammonium adsorption in superficial North Sea sediments. Cont. Shelf Res. 1996, 16, 14151435.

(64) Ceazan, M. L.; Thurman, E. M.; Smith, R. L. Retardation of Ammonium and Potassium-Transport through a Contaminated Sand and Gravel Aquifer - the Role of Cation-Exchange. Environ. Sci. Technol. 1989, 23, 1402-1408.

(65) Seitzinger, S. P.; Gardner, W. S.; Spratt, A. K. The Effect of Salinity on Ammonium Sorption in Aquatic Sediments - Implications for Benthic Nutrient Recycling. Estuaries 1991, 14, 167-174.

(66) Zhang, J. Z.; Huang, X. L. Effect of Temperature and Salinity on Phosphate Sorption on Marine Sediments. Environ. Sci. Technol. 2011, 45, 6831-6837.

(67) $100 \mathrm{~L} / \mathrm{kg}$ represents concentrations of $10-100 \mathrm{mg}$ exchangeable $\mathrm{P} / \mathrm{kg}$ sediment. Depending on concentration and whether the value represents $\mathrm{P}$ or $\mathrm{PO}_{4}, \mathrm{~K}_{\mathrm{d}}$ widely differs: $\mathrm{K}_{\mathrm{d}}=160,000 \mathrm{~L} / \mathrm{kg}$ for $\mathrm{P}$ (Tang et al. 2017) and $K_{d}=2,500$ for inorganic $P_{4}$ in the River Great Ouse, England (Prastka et al. 1998).

(68) Crommentuijn, T.; Polder, M. D.; van de Plassche, E. J. Maximum Permissible Concentrations and Negligible Concentrations for metals, taking background concentrations into account; National Institute of Public Health and the Environment: Bilthoven, the Netherlands, 1997.

(69) Zhang, C.; Yu, Z. G.; Zeng, G. M.; Jiang, M.; Yang, Z. Z.; Cui, F.; Zhu, M. Y.; Shen, L. Q.; Hu, L. Effects of sediment geochemical properties on heavy metal bioavailability. Environ. Int. 2014, 73, 270281.

(70) Bruijn, J. H. M.; Denneman, C. A. J. Achtergrondgehalten van negen sporen-metalen in oppervlaktewater, grondwater en grond van Nederland; 1992.

(71) Kim, S.; Thiessen, P. A.; Bolton, E. E.; Chen, J.; Fu, G.; Gindulyte, A.; Han, L.; He, J.; He, S.; Shoemaker, B. A.; Wang, J.; Yu, B.; Zhang, J.; Bryant, S. H. PubChem Substance and Compound databases. Nucleic Acids Res. 2016, 44, D1202-D1213.

(72) Mackay, D.; Shiu, W. Y.; Ma, K. C.; Lee, S. C. Handbook of physical-chemical properties and environmental fate for organic chemicals; CRC Press Inc.: Boca Raton, USA, 2006; 4216. 
(73) Arnold, C. G. Triorganotin Compounds in Natural Waters and Sediments: Aqueous Speciation and Sorption Mechanisms Swiss Federal Institute of Technology Zurich; 1998.

(74) Henriksen, K.; Rasmussen, M. B.; Jensen, A. Effect of Bioturbation on Microbial Nitrogen Transformations in the Sediment and Fluxes of Ammonium and Nitrate to the Overlaying Water. Ecol. Bull. 1983, 35, 193-205.

(75) Berg, M.; Arnold, C. G.; Müller, S. R.; Mühlemann, J.; Schwarzenbach, R. P. Sorption and desorption behavior of organotin compounds in sediment-pore water systems. Environ. Sci. Technol. 2001, 35, 3151-3157.

(76) Xiao, X.; Sheng, G. D.; Qiu, Y. Improved Understanding of Tributyltin Sorption on Natural and Biochar-Amended Sediments. Environ. Toxicol. Chem. 2011, 30, 2682-2687.

(77) USEPA Ecotox Database.

(78) Ankley, G. T.; Schubauer-Berigan, M. K.; Monson, P. D. Influence of $\mathrm{pH}$ and hardness on toxicity of ammonia to the amphipod Hyalella azteca. Can. J. Fish. Aquat. Sci. 1995, 52, 20782083.

(79) Bowen, H. J. M.; Blunden, S. J.; Hobbs, L. A.; Smith, P. J. The environmental chemistry of organotin compounds. Environ. Chem. 1984, 3, 49-77.

(80) Fent, K. Ecotoxicology of organotin compounds. Crit. Rev. Toxicol. 1996, 26, 3-117.

(81) Meador, J. P. Predicting the fate and effects of tributyltin in marine systems: Section IV. Bioaccumulation A. Tissue-Water Partitioning. In Reviews of Environmental Contamination and Toxicology: Ware, G. W., Ed., Springer: New York, USA, 2000; 166, $1-48$.

(82) Fang, L.; Borggaard, O. K.; Christensen, J. H.; Holm, P. E.; Hansen, H. C. B. Adsorption of mono- and di-butyltin by a wheat charcoal: $\mathrm{pH}$ effects and modeling. Chemosphere 2012, 89, 863-868.

(83) Beyer, W. N.; Meador, J. P. Environmental Contaminants in Biota: Interpreting Tissue Concentrations. 2nd ed.; CRC Press: 2011, DOI: $10.1201 / \mathrm{b} 10598$.

(84) Mohamed, M.; Mohamed, A.; Shoukry, M. M. Interaction of diphenyltin(IV) dichloride with some selected bioligands. Chem. Pharm. Bull. 2001, 49, 253-257.

(85) Berry, W. J.; Boothman, W. S.; Serbst, J. R.; Edwards, P. A. Predicting the toxicity of chromium in sediments. Environ. Toxicol. Chem. 2004, 23, 2981-2992.

(86) Besser, J. M.; Brumbaugh, W. G.; Kemble, N. E.; May, T. W.; Ingersoll, C. G. Effects of sediment characteristics on the toxicity of chromium(III) and chromium(VI) to the amphipod, Hyalella azteca. Environ. Sci. Technol. 2004, 38, 6210-6216.

(87) Hu, Y.; Chen, N.; Li, M.; Feng, C.; Liu, T. Insights into simultaneous microbial chromium and nitrate reduction: inhibitory effects and molecular mechanisms. J. Chem. Technol. Biotechnol. 2019, 94, 2589-2596.

(88) Chovanec, P.; Sparacino-Watkins, C.; Zhang, N.; Basu, P.; Stolz, J. F. Microbial reduction of chromate in the presence of nitrate by three nitrate respiring organisms. Front. Microbiol. 2012, 3, 416.

(89) Viamajala, S.; Peyton, B. M.; Apel, W. A.; Petersen, J. N. Chromate/nitrite interactions in Shewanella oneidensis MR-1: Evidence for multiple hexavalent chromium [Cr(VI)] reduction mechanisms dependent on physiological growth conditions. Biotechnol. Bioeng. 2002, 78, 770-778.

(90) Wang, S.; Choi, J. H. Simulating fate and transport of chromium in saturated sediments. Appl. Math. Model. 2013, 37, 102111.

(91) Rosales, R. M.; Faz, A.; Gómez-Garrido, M.; Muñoz, M. A.; Murcia, F. J.; González, V.; Acosta, J. A. Geochemical speciation of chromium related to sediments properties in the riverbed contaminated by tannery effluents. J. Soils Sediments 2017, 17, $1437-1448$

(92) Hassan, S. M.; Garrison, A. W. Distribution of chromium species between soil and porewater. Chem. Speciation Bioavailability 1996, 8, 85-103.
(93) Blunden, S. J.; Chapman, A. Organomettalic Compounds in the Environment. Principles and Reactions; Craig, P. J. E., Ed. Longman Group Ltd.: Essex, U.K., 1986; 111-159.

(94) Nikinmaa, M. What Causes Aquatic Contamination?. In $A n$ Introduction to Aquatic Toxicology; Elsevier: 2014.

(95) Kudłak, B.; Wolska, L.; Namieśnik, J. Determination of EC $_{50}$ toxicity data of selected heavy metals toward Heterocypris incongruens and their comparison to "direct-contact" and microbiotests. Environ. Monit. Assess. 2011, 174, 509-516.

(96) Yulievna, S. N.; Rinatovna, L. T.; Victorovna, N. L. Comparison of Toxicity of Sediments from Rivers with Different Levels of Anthropogenic Load (Middle Volga Region, Russia) Based on Elutriate and Whole Sediment Tests. Uchenye Zapiski Kazanskogo Universiteta-Seriya Estestvennye Nauki 2016, 158, 416-439.

(97) Khangarot, B. S.; Das, S. Acute toxicity of metals and reference toxicants to a freshwater ostracod, Cypris subglobosa Sowerby, 1840 and correlation to $\mathrm{EC}_{50}$ values of other test models. J. Hazard. Mater. 2009, 172, 641-649.

(98) de Zwart, D.; Posthuma, L. Complex mixture toxicity for single and multiple species: proposed methodologies. Environ. Toxicol. Chem. 2005, 24, 2665-2676.

(99) Van Regenmortel, T.; Nys, C.; Janssen, C. R.; Lofts, S.; De Schamphelaere, K. A. C. Comparison of Four Methods for Bioavailability-Based Risk Assessment of Mixtures of $\mathrm{Cu}, \mathrm{Zn}$, and $\mathrm{Ni}$ in Freshwater. Environ. Toxicol. Chem. 2017, 36, 2123-2138.

(100) Sprague, J. B. Measurement of pollutant toxicity to fish. II. Utilizing and applying bioassay results. Water Res. 1970, 4, 3-32.

(101) International Organization for Standardization ISO 14371. Water quality: Determination of freshwater sediment toxicity to Hetrocypris incongruens (Crustacea, Ostracoda). 2012.

(102) Chial, B.; Persoone, G. Cyst-based toxicity tests XIIdevelopment of a short chronic sediment toxicity test with the ostracod crustacean Heterocypris incongruens: selection of test parameters. Environ. Toxicol. 2002, 17, 520-527.

(103) Ruz, P. M.; Hidalgo, P.; Yáñez, S.; Escribano, R.; Keister, J. E. Egg production and hatching success of Calanus chilensis and Acartia tonsa in the northern Chile upwelling zone $\left(23^{\circ} \mathrm{S}\right)$, Humboldt Current System. J. Mar. Syst. 2015, 148, 200-212.

(104) Raikow, D. F.; Reid, D. F.; Blatchley, E. R.; Jacobs, G.; Landrum, P. F. Effects of proposed physical ballast tank treatments on aquatic invertebrate resting eggs. Environ. Toxicol. Chem. 2007, 26, $717-725$

(105) Kim, Y.; Mo, H.; Son, J.; Lee, Y.; Lee, S.; Cho, K. Interactive effects of water $\mathrm{pH}$ and hardness levels on the growth and reproduction of Heterocypris incongruens (Crustacea: Ostracoda). Hydrobiologia 2015, 753, 97-109.

(106) Chial, B.; Persoone, G. Cyst-based toxicity tests XIII Development of a short chronic sediment toxicity test with the ostracod crustacean Heterocypris incongruens: Methodology and precision. Environ. Toxicol. 2002, 17, 528-532.

(107) EPA Consideration of the FQPA safety factor and other uncertainty factors in cumulative risk assessment of chemicals charing a common mechanism of toxicity; Washington, 2002.

(108) de Vries, W.; Schütze, G.; Lofts, S.; Meili, M.; Römkens, P. F. A. M.; Farret, R.; De Temmerman, L.; Jakubowski, M. Critical limits for cadmium, lead and mercury related to ecotoxicological effects on soil organisms, aquatic organisms, plants, animals and humans. In Proceedings expert meeting on critical limits for heavy metals and methods for their application, Berlin, Germany, 2-4 December 2002. Expert meeting on critical limits for heavy metals and methods for their application; Berlin (Germany), Umweltbundesamt: 2003; 29-78.

(109) Song, C. W.; Griffin, R. J.; Park, H. J. Influence of Tumor pH on Therapeutic Response. In Cancer Drug Resistance; Humana Press: 2006; 21-42, DOI: 10.1007/978-1-59745-035-5 2.

(110) Carter, N. W. Intracellular pH. Kidney Int. 1972, 1, 341-346.

(111) White, J. S.; Tobin, J. M. Role of speciation in organotin toxicity to the yeast Candida maltosa. Environ. Sci. Technol. 2004, 38, $3877-3884$ 
(112) Tsuda, T.; Aoki, S.; Kojima, M.; Harada, H. The influence of $\mathrm{pH}$ on the accumulation of tri- $n$-butyltin chloride and triphenyltin chloride in carp. Comp. Biochem. Physiol. 1990, 95, 151-153.

(113) Arnold, C. G.; Weidenhaupt, A.; David, M. M.; Müller, S. R.; Haderlein, S. B.; Schwarzenbach, R. P. Aqueous speciation and 1octanol-water partitioning of tributyl- and triphenyltin: Effect of $\mathrm{pH}$ and ion composition. Environ. Sci. Technol. 1997, 31, 2596-2602.

(114) Hunziker, R. W.; Escher, B. I.; Schwarzenbach, R. P. pH dependence of the partitioning of triphenyltin and tributyltin between phosphatidylcholine liposomes and water. Environ. Sci. Technol. 2001, 35, 3899-3904.

(115) Fent, K. Effects of organotin compounds in fish: from the molecular to the population level. In Fish Ecotoxicology; Braunbeck, T.; Hinton, D. E.; Streit, B., Ed. Birkhauser Verlag: basel, Switzerland, 1998; 265-267.

(116) Escher, B. I.; Ashauer, R.; Dyer, S.; Hermens, L. J. M.; Lee, J.H.; Leslie, H. A.; Mayer, P.; Meador, J. P.; Warne, M. S. J. Crucial role of mechanisms and modes of toxic action for understanding tissue residue toxicity and internal effect concentrations of organic chemicals. Integr. Environ. Assess. Manage. 2010, 7, 28-49.

(117) Verhaegen, Y. Mechanism, Concentrations and Effects of Tributyltin in Common Shrimp Crangon crangon; Ghent University: Ghent, 2012.

(118) Verhaegen, Y.; Parmentier, K.; Swevers, L.; Rougé, P.; Soin, T.; De Coen, W.; Cooreman, K.; Smagghe, G. The brown shrimp (Crangon crangon L.) ecdysteroid receptor complex: Cloning, structural modeling of the ligand-binding domain and functional expression in an EcR-deficient Drosophila cell line. Gen. Comp. Endocrinol. 2010, 168, 415-423.

(119) Song, Y.; Villeneuve, D. L.; Toyota, K.; Iguchi, T.; Tollefsen, K. E. Ecdysone Receptor Agonism Leading to Lethal Molting Disruption in Arthropods: Review and Adverse Outcome Pathway Development. Environ. Sci. Technol. 2017, 51, 4142-4157.

(120) Yavuzatmaca, M.; Kulkoyluoglu, O.; Yilmaz, O.; Akdemir, D. On the Relationship of Ostracod Species (Crustacea) to Shallow Water Ion and Sediment Phosphate Concentration Across Different Elevational Range (Sinop, Turkey). Turkish J. Fish. Aquat. Sci. 2017, 17, 1333-1346.

(121) Keyser, D.; Walter, R. Calcification in ostracodes. Revista Española de Micropaleontologia 2004, 36, 1-11.

(122) Mulligan, R. M. Metastatic Calcification. Arch. Pathol. 1947, 43, 177-230.

(123) Lotsari, A.; Rajasekharan, A. K.; Halvarsson, M.; Andersson, M. Transformation of amorphous calcium phosphate to bone-like apatite. Nat. Commun. 2018, 9, 4170.

(124) Mekmene, O.; Touillon, T.; Bouler, J.-M.; Piot, M.; Gaucheron, F. Effects of $\mathrm{pH}$ and $\mathrm{Ca} / \mathrm{P}$ molar ratio on the quantity and crystalline structure of calcium phosphates obtained from aqueous solutions. Dairy Sci. Technol. 2009, 89, 301-316.

(125) Willard, L. L. Chemical equilibria in soils. John Wiley \& Sons, Inc.: New York, 1979.

(126) Word, J.; Moore, D.; Irwin, M. A.; Cooper, A. Acute and Chronic Toxicity of Ammonia to the Amphipod Hyalella azteca under Hard Water Conditions. Soil Sediment Contam. 2002, 11, 487-488.

(127) Anderson, B.; Nicely, P.; Gilbert, K.; Kosaka, R.; Hunt, J.; Phillips, B. Overview of Freshwater and Marine Toxicity Tests: A technical tool for ecological rish assessment; Department of Environmental Toxicology, University of California Davis: 2004.

(128) Weihrauch, D.; Fehsenfeld, S.; Quijada-Rodriguez, A. 1.2.2 Toxicity of Ammonia in Crustaceans. In Acid-Base Balance and Nitrogen Excretion in Invertebrates - Mechanisms and strategies in various invetebrate groups with considerations of challenges caused by ocean acidification, Weihrauch, D.; O’Donnel, M., Ed.; Springer: 2017.

(129) Monfort, P.; Kosenko, E.; Erceg, S.; Canales, J. J.; Felipo, V. Molecular mechanism of acute ammonia toxicity: role of NMDA receptors. Neurochem. Int. 2002, 41, 95-102.

(130) Li, M.; Costello, D. M.; Burton, G. A. Interactive effects of phosphorus and copper on Hyalella azteca via periphyton in aquatic ecosystems. Ecotoxicol. Environ. Saf. 2012, 83, 41-46.
(131) Chu, K. W.; Chow, K. L. Synergistic toxicity of multiple heavy metals is revealed by a biological assay using a nematode and its transgenic derivative. Aquat. Toxicol. 2002, 61, 53-64.

(132) Kamaya, Y.; Takada, T.; Suzuki, K. Effect of medium phosphate levels on the sensitivity of Selenastrum capricomutum to chemicals. Bull. Environ. Contam. Toxicol. 2004, 73, 995-1000.

(133) Daneshgar, S.; Buttafava, A.; Capsoni, D.; Callegari, A.; Capodaglio, A. G. Impact of $\mathrm{pH}$ and Ionic Molar Ratios on Phosphorous Forms Precipitation and Recovery from Different Wastewater Sludges. Resources 2018, 7, 71.

(134) Hynes, M. J.; O’Dowd, M. Interactions of the Trimethyltin(IV) Cation with Carboxylic-Acids, Amino-Acids, and Related Ligands. J. Chem. Soc., Dalton Trans. 1987, 3, 563-566.

(135) Tsagkatakis, I.; Chaniotakis, N.; Altmann, R.; Jurkschat, K.; Willem, R.; Martins, J. C.; Qin, Y.; Bakker, E. Phosphate-binding characteristics and selectivity studies of bifunctional organotin carriers. Helv. Chim. Acta 2001, 84, 1952-1961.

(136) Ditsch, L.; Swanson, R.; Milun, A. J. Feasibility of liquid ion exchange for extracting phosphate from wastewater; 1970.

(137) Staniszewska, M.; Radke, B.; Namieśnik, J.; Bolalkek, J. Analytical methods and problems related to the determination of organotin compounds in marine sediments. Int. J. Environ. Anal. Chem. 2008, 88, 747-774.

(138) Grigarick, A. A.; Webster, R. K.; Meyer, R. P.; Zalom, F. G.; Smith, K. A.; Smith, K. A.; Grigarick, A. A. Effect of Pesticide Treatments on Nontarget Organisms in California Rice Paddies .1. Impact of Triphenyltin Hydroxide .2. Impact of Diflubenzuron and Triflumuron. Hilgardia 1990, 58, 1-36.

(139) Shoukry, M. M.; Al-Alousi, A.; Tarek, S. M. Diorganotin(IV) Complexes with Methionine Methyl Ester. Equilibria and Displacement by DNA Constituents. S. Afr. J. Chem. 2014, 67, 94-98.

(140) Immel, F.; Broussard, C.; Catherinet, B.; Plasseraud, L.; Alcaraz, G.; Bundeleva, I.; Marin, F. The Shell of the Invasive Bivalve Species Dreissena polymorpha: Biochemical, Elemental and Textural Investigations. PLoS One 2016, 11, e0154264.

(141) Milhau, B.; Dekens, N.; Wouters, K. Evaluation de l'utilisation des ostracodes comme bio-indicateurs potentiels de pollution; 1997.

(142) Pacioglu, O.; Moldovan, O. T. Response of invertebrates from the hyporheic zone of chalk rivers to eutrophication and land use. Environ. Sci. Pollut. Res. 2016, 23, 4729-4740.

(143) Danielopol, D. L.; Geiger, W.; Tölderer-Farmer, M.; Orellana, C. P.; Terrat, M. N. The Ostracoda of Mondsee: spatial and temporal changes during the last 50 years. In Contributions to the Paleolimnology of the Trumer Lakes (Salzburg) and Lake Mondsee, Attersee and Traunsee (Upper Austria); Limnologisches Institut der Osterreichischen Akademie der Wischenschaften: Mondsee, 1985.

(144) Soucek, D. J.; Dickinson, A. Influence of chloride on the chronic toxicity of sodium nitrate to Ceriodaphnia dubia and Hyalella azteca. Ecotoxicology 2016, 25, 1406-1416.

(145) Wilbur, S.; Abadin, H.; Fay, M.; Yu, D.; Tencza, B.; Ingerman, L.; Klotzbach, J.; James, S. Toxicological Profile for Chromium. Agency for Toxic Substances and Disease Registry (ATSDR) Toxicological Profiles; 2012.

(146) Sangwan, P.; Kumar, V.; Gulati, D.; Joshi, U. N. Interactive effects of salicylic acid on enzymes of nitrogen metabolism in clusterbean (Cyamopsis tetragonoloba L.) under chromium(VI) toxicity. Biocatal. Agric. Biotechnol. 2015, 4, 309-314.

(147) Fumasoli, A.; Bürgmann, H.; Weissbrodt, D. G.; Wells, G. F.; Beck, K.; Mohn, J.; Morgenroth, E.; Udert, K. M. Growth of Nitrosococcus-Related Ammonia Oxidizing Bacteria Coincides with Extremely Low $\mathrm{pH}$ Values in Wastewater with High Ammonia Content. Environ. Sci. Technol. 2017, 51, 6857-6866.

(148) Strand, J.; Jacobsen, J. A. Accumulation and trophic transfer of organotins in a marine food web from the Danish coastal waters. Sci. Total Environ. 2005, 350, 72-85.

(149) Elsenhans, B.; Schuman, K.; Forth, W. Metal-Metal Toxic Interactions. In Handbook of Hazardous Materials; Corn, M., Ed.; Academic Press, Inc.: San Diego, 1993; p 435. 
(150) Borgmann, U.; Nowierski, M.; Dixon, D. G. Effect of major ions on the toxicity of copper to Hyalella azteca and implications for the biotic ligand model. Aquat. Toxicol. 2005, 73, 268-287.

(151) Hare, L.; Carignan, R.; Huerta-Diaz, M. A. A Field-Study of Metal Toxicity and Accumulation by Benthic Invertebrates Implications for the Acid Volatile Sulfide (Avs) Model. Limnol. Oceanogr. 1994, 39, 1653-1668.

(152) Sun, H.; Huang, G.; Dal, S. Adsorption behaviour and QSPR studies of organotin compounds on estuarine sediment. Chemosphere 1996, 33, 831-838.

(153) Nolte, T. M.; Ragas, A. M. J. A review of quantitative structure-property relationships for the fate of ionizable organic chemicals in water matrices and identification of knowledge gaps. Environ. Sci.: Processes Impacts 2017, 19, 221-246.

(154) Tipping, E. Humic ion-binding model VI: An improved description of the interactions of protons and metal ions with humic substances. Aquat. Geochem. 1998, 4, 3-47.

(155) Verschoor, A. J.; Vijver, M. G.; Vink, J. P. M. Refinement and Cross-Validation of Nickel Bioavailability in Pnec-Pro, a Regulatory Tool for Site-Specific Risk Assessment of Metals in Surface Water. Environ. Toxicol. Chem. 2017, 36, 2367-2376.

(156) Vink, J. P. M.; Meeussen, J. C. L. BIOCHEM-ORCHESTRA: A tool for evaluating chemical speciation and ecotoxicological impacts of heavy metals on river flood plain systems. Environ. Pollut. 2007, $148,833-841$.

(157) Sor, R.; Boets, P.; Lek, S.; Goethals, P. Spatio-temporal cooccurrence of alien and native molluscs: a modelling approach using physical-chemical predictors. Aquat. Invasions 2017, 12, 147-158.

(158) Denys, L. Relation of abundance-weighted averages of diatom indicator values to measured environmental conditions in standing freshwaters. Ecol. Indic. 2004, 4, 255-275.

(159) Stoica, C.; Gheorghe, S.; Lucaciu, E. I.; Stanescu, E.; Paun, C. I.; Niculescu, L. D. The Impact of Chemical Compounds on Benthic Invertebrates from the Danube and Danube Delta Systems. Soil Sediment Contam. 2014, 23, 763-778.

(160) Zarcinas, B. A.; Rogers, S. L. Copper, lead and zinc mobility and bioavailability in a river sediment contaminated with paint stripping residue. Environ. Geochem. Health 2002, 24, 191-203.

(161) Gao, J. M.; Fu, P. T.; Chen, X. L.; Guo, J. S.; Hou, X. Y.; Zeng, J.; Chen, Z. M. Fate simulation and risk assessment of TBT and TPhT considering water level fluctuations in the TGR before and after AFS Convention implementation in China. Environ. Sci. Eur. 2020, 32, 16. 